\title{
Enzyme replacement therapy for pancreatic insufficiency: present and future
}

This article was published in the following Dove Press journal:

Clinical and Experimental Gastroenterology

3 May 201I

Number of times this article has been viewed

\author{
Aaron Fieker' \\ Jessica Philpott ${ }^{\prime}$ \\ Martine Armand ${ }^{2}$ \\ 'Division of Digestive Diseases, \\ University of Oklahoma, OKC, \\ OK, USA; ${ }^{2} I N S E R M$, U476 \\ "Nutrition Humaine et Lipides", \\ Marseille, F-I 3385 France; Univ \\ Méditerranée Aix-Marseille 2, \\ Faculté de Médecine, IPHM-IFR \\ I25, Marseille, F-I3385 France
}

Correspondence: Martine Armand INSERM, U476 "Nutrition Humaine et Lipides", Marseille, F-I 3385 France; Univ Méditerranée Aix-Marseille 2, Faculté de Médecine, IPHM-IFR I25, Marseille, F-I3385 France

Tel +33491782101

Fax +33491294093

Email martine.armand@univmed.fr

\begin{abstract}
Pancreatic enzyme replacement therapy is currently the mainstay of treatment for nutrient malabsorption secondary to pancreatic insufficiency. This treatment is safe and has few side effects. Data demonstrate efficacy in reducing steatorrhea and fat malabsorption. Effective therapy has been limited by the ability to replicate the physiologic process of enzyme delivery to the appropriate site, in general the duodenum, at the appropriate time. The challenges include enzyme destruction in the stomach, lack of adequate mixing with the chyme in the duodenum, and failing to deliver and activate at the appropriate time. Treatment is begun when clinically significant malabsorption occurs resulting in steatorrhea and weight loss. Treatment failure is addressed in a sequential fashion. Current research is aimed at studying new enzymes and delivery systems to improve the efficiency of action in the duodenum along with developing better means to monitor therapy.
\end{abstract}

Keywords: exocrine pancreatic insufficiency, chronic pancreatitis, cystic fibrosis, pancreatic enzyme replacement therapy, lipase, lipids

\section{Introduction}

Normal pancreatic function ensures effective digestion and absorption of nutrients. Clinical exocrine pancreatic insufficiency occurs when secretions of the pancreas do not maintain normal digestive function, resulting in nutrient malabsorption and other symptoms such as diarrhea, which in turn affect quality of life and eventually result in malnutrition. ${ }^{1-3}$ The leading cause of pancreatic insufficiency is chronic pancreatitis, which is estimated to affect $0.4 \%$ to $5 \%$ of the world population. ${ }^{4}$ In children, however, the most common cause of pancreatic insufficiency is cystic fibrosis. The reported prevalence of exocrine pancreatic insufficiency in chronic pancreatitis and cystic fibrosis is $30 \%$ to $40 \%$ and $80 \%$ to $90 \%$ respectively. ${ }^{5}$ The use of oral therapy pre-dates the creation of the US Food and Drug Administration (FDA) in 1938, and currently enzyme replacement is the mainstay of therapy in patients diagnosed with malabsorption secondary to pancreatic insufficiency.

In order to manage patients effectively with malabsorption related to exocrine pancreatic insufficiency, an understanding of normal pancreatic physiology and pathophysiology is required. This review provides an overview of normal pancreatic function and the biochemistry of lipid digestion, along with the pathophysiologic mechanisms of disease that lead to malabsorption. Enzyme replacement therapy is reviewed including the pharmacokinetics, various preparations, dosing, and side effects. The inadequacy of current therapy has led to ongoing research, which is reviewed in 
detail to examine how this has improved our understanding of lipid digestion and also the therapy we have to offer.

\section{Normal exocrine pancreatic physiology Composition and regulation of pancreatic fluid secretion}

The exocrine pancreas plays a key role in the digestive function through the secretion of pancreatic juice consisting of numerous enzymes and of aqueous solution rich in sodium bicarbonate. Postprandial secretion can increase up to 1 to $2 \mathrm{~L}$ per day. ${ }^{6-8}$ Three main types of enzymes are secreted to digest the ingested macronutrients: proteins (trypsinogen 1 , 2, and 3, chymotrypsinogen, proelastase 1 and 2, protease $\mathrm{E}$, kallikreinogen, procarboxypeptidase A1, A2, B1, and B2), starchy foods ( $\alpha$-amylase), and lipids (Table 1). ${ }^{9-21}$ While lipases and amylase are secreted in the active form, proteases are secreted as pro-enzymes. Trypsinogen is converted to its active form trypsin in the duodenum by enterokinase, a protease secreted by the enterocytes, and trypsin in turn activates the other pancreatic proteases.

Enzyme content of pancreatic fluid changes according to different factors including age, gender, and diet. The pancreas reaches mature function by 2 years of age, ${ }^{22}$ and enzyme secretion is lower in full-term newborns and young

Table I Human pancreatic enzymes involved in lipid digestion

\begin{tabular}{|c|c|c|}
\hline Enzyme name & Specific substrate & References \\
\hline $\begin{array}{l}\text { Pancreatic } \\
\text { lipase }\end{array}$ & Triglycerides (lipid-droplet) & $10,16,19$ \\
\hline $\begin{array}{l}\text { Pancreatic lipase } \\
\text { related protein I }\end{array}$ & $\begin{array}{l}\text { Unknown } \\
\text { Inhibitory effect of HPL } \\
\text { (regulatory effect of TG } \\
\text { digestion in the duodenum?) }\end{array}$ & $\begin{array}{l}11,12 \\
9\end{array}$ \\
\hline \multirow[t]{2}{*}{$\begin{array}{l}\text { Pancreatic lipase } \\
\text { related protein } 2\end{array}$} & $\begin{array}{l}\text { Triglycerides } \\
\text { (milk lipid-droplet) } \\
\text { Synergistic effect of HPL } \\
\text { (regulatory effect of TG } \\
\text { digestion in the duodenum?) }\end{array}$ & 9 \\
\hline & $\begin{array}{l}\text { Phospholipids } \\
\text { Galactolipids } \\
\text { Esters of vitamin A }\end{array}$ & $\begin{array}{l}15,19 \\
13,18 \\
17\end{array}$ \\
\hline \multirow[t]{2}{*}{ Carboxyl ester lipase } & $\begin{array}{l}\text { Esters of lipid-soluble vitamins } \\
\text { Esters of cholesterol } \\
\text { Triglycerides, diglycerides, } \\
\text { monoglycerides }\end{array}$ & $\begin{array}{l}14 \\
14 \\
14\end{array}$ \\
\hline & $\begin{array}{l}\text { Phospholipids } \\
\text { Ceramides }\end{array}$ & $\begin{array}{l}14 \\
14\end{array}$ \\
\hline Phospholipase A2 & Phospholipids & 20 \\
\hline
\end{tabular}

Abbreviations: HPL, human pancreatic lipase; TG, triglycerides. infants than in adults. ${ }^{22-25}$ Pancreatic secretion in the elderly is decreased, with as little as $56 \%$ of young adult function maintained, but the clinical impact is controversial. ${ }^{26,27}$ Men may have higher levels of secretion than women but the physiological relevance is not documented. ${ }^{27}$ Pancreatic fluid composition varies highly among individuals. ${ }^{7,28-31}$ Amount and type of lipids consumed might explain in part this individual variability. Indeed, a 2-week high-fat/lowcarbohydrate diet is associated with a 4-fold higher pancreatic enzyme output in healthy humans compared with a diet rich in carbohydrates or proteins. ${ }^{32}$ Pancreatic lipase levels in the human duodenum vary with the quantity and the type of lipids ingested during a single meal. ${ }^{29,30,33-36}$ The rate of pancreatic enzyme degradation in the small intestinal lumen also varies among individuals. ${ }^{37}$ As a result of these variables, determining the exact enzyme level secreted by the normal human pancreas is difficult. Furthermore, varying methods used for collection and measurement of activity result in data that are not directly comparable. Pancreatic or duodenal juice is collected using solid or liquid meal, $7,24,28,30,31,34-36,38,39$ or after direct hormonal stimulation ${ }^{8,22,23,40,41}$ or through baseline..$^{24,39,42,43}$ Enzyme activity measurements are in general done under optimized assay conditions and do not indicate the real activity in vivo. ${ }^{28,38}$ Data are available as enzyme activities or output expressed as Units (U) per minute or $U$ per hour, $U$ per milliliter, or as milligrams of secreted enzymes (Tables 2 and 3). ${ }^{7,822-24,29-31,34-36,40-45}$ To make the comparisons easier, enzyme activities are generally expressed as International Units (IU). One IU is defined as the amount of enzyme required to release $1 \mu$ mole of product from the used substrate per $\mathrm{mL}$ per min under the standard assay conditions.

There is a specific orchestration of the pancreatic fluid secretion during the fed state leading to appropriate enzyme delivery on demand in the duodenum. During the cephalic phase, orosensory perception of lipids seems to increase pancreatic secretion. ${ }^{46-49}$ During the gastric phase, digestion of proteins by pepsin and of triglycerides by gastric lipase generates amino acids and free fatty acids, respectively. ${ }^{50,51}$ When delivered through the pylorus, they become powerful stimulants of the cholecystokinin hormone (CCK) produced by the duodenal endocrine cells which stimulates pancreatic enzymes secretion and controls the gastric emptying rate. ${ }^{49}$ The acidic $\mathrm{pH}$ of the chyme entering the duodenum stimulates the release of secretin, which increases the secretion of water and bicarbonate ions from the pancreas. ${ }^{49}$ This gastric phase of digestion represents an important aspect in the overall postprandial regulation of pancreatic secretion that becomes abnormal after gastric surgery when gastric digestion and emptying are altered..$^{52,53}$ 
Table 2 Baseline and postprandial activity of the main pancreatic enzymes in healthy humans ${ }^{\mathrm{a}}$

\begin{tabular}{|c|c|c|c|c|}
\hline & Activity (Units) ${ }^{\mathrm{b}}$ & Collection condition & Method of measurement & Age, number, references \\
\hline \multicolumn{5}{|c|}{ Full-term infants } \\
\hline \multirow[t]{5}{*}{ Lipase } & $106 \mid \pm 101$ & CCK + secretin & Olive oil emulsion, $\mathrm{pH} 9,25^{\circ} \mathrm{Cm}$ & $7 \mathrm{mo}, \mathrm{n}=18$, Palasciano ${ }^{41}$ \\
\hline & $982(49-978)$ & $\mathrm{CCK}+$ secretin & Olive oil emulsion, $\mathrm{pH} 9.1,37^{\circ} \mathrm{C}^{\mathrm{m}}$ & At birth, $n=8$, Zoppi $^{23}$ \\
\hline & $20 / 50 / 600$ & Baseline & Olive oil emulsion, $\mathrm{pH} 8$ & $\mathrm{I} \mathrm{d} / \mathrm{I} \mathrm{mo} / 2 \mathrm{yr}, \mathrm{n}=15$, Lebenthal $^{22}$ \\
\hline & $20 / 50 / 1400$ & CCK & Olive oil emulsion, $\mathrm{pH} 8$ & I d/I mo/2 yr, $\mathrm{n}=15$, Lebenthal ${ }^{22}$ \\
\hline & $107 \mid \pm 143$ & CCK + secretin & Olive oil emulsion, $\mathrm{pH} 9.1,37^{\circ} \mathrm{Cm}$ & I0-I44 mo, $\mathrm{n}=7$, Moreau $^{40}$ \\
\hline Phospholipase & $16.7 \pm 1.9$ & CCK + secretin & Egg-yolk lipoprotein, $\mathrm{pH} 8,40^{\circ} \mathrm{C}$ & $7 \mathrm{mo}, \mathrm{n}=18$, Palasciano ${ }^{41}$ \\
\hline \multirow[t]{3}{*}{ Trypsin } & $45 \mathrm{I}(27-1328) \mu \mathrm{g}$ & CCK + secretin & BAEE, $\mathrm{pH} 8,25^{\circ} \mathrm{C}^{\mathrm{n}}$ & At birth, $n=8$, Zoppi ${ }^{23}$ \\
\hline & $180 / 325 / / 80$ & Baseline & BAPNA, $\mathrm{pH} 8.2,25^{\circ} \mathrm{C}^{\circ}$ & I d/I mo/2 yr, $n=15$, Lebenthal ${ }^{22}$ \\
\hline & $170 / 280 / 400$ & CCK & BAPNA, $\mathrm{pH} 8.2,25^{\circ} \mathrm{C}^{\circ}$ & $\mathrm{I} \mathrm{d} / \mathrm{I} \mathrm{mo} / 2 \mathrm{yr}, \mathrm{n}=\mid \mathrm{5}$, Lebenthal ${ }^{22}$ \\
\hline \multirow[t]{3}{*}{ Chymotrypsin } & $93 \pm 9$ & $\mathrm{CCK}+$ secretin & ATEE, $\mathrm{pH} 7.9,25^{\circ} \mathrm{C}$ & $7 \mathrm{mo}, \mathrm{n}=18$, Palasciano ${ }^{41}$ \\
\hline & $5-7.5-12.5$ & Baseline & BTEE, $\mathrm{pH} 7.2-8.0,30^{\circ} \mathrm{C}$ & I $\mathrm{d} / \mathrm{I} \mathrm{mo} / 2 \mathrm{yr}, \mathrm{n}=\mid \mathrm{5}$, Lebenthal $\left.\right|^{22}$ \\
\hline & $7-9-25$ & $\mathrm{CCK}$ & BTEE, $\mathrm{pH} 7.2-8.0,30^{\circ} \mathrm{C}$ & I d/I mo/2 yr, $\mathrm{n}=15$, Lebenthal ${ }^{22}$ \\
\hline \multirow[t]{4}{*}{ Amylase } & $22(2-37)$ & CCK + secretin & Starch, $\mathrm{pH} 6.9,25^{\circ} \mathrm{C}$ & At birth, $\mathrm{n}=8$, Zoppi $\mathrm{i}^{23}$ \\
\hline & 0 & Baseline or CCK & Starch & I d/I mo, $n=\mid 5$, Lebenthal ${ }^{22}$ \\
\hline & 225 & Baseline & Starch & $2 y r, n=15$, Lebenthal $^{22}$ \\
\hline & 300 & CCK & Starch & $2 y r, n=15$, Lebentha $^{22}$ \\
\hline \multicolumn{5}{|l|}{ Adults } \\
\hline \multirow[t]{17}{*}{ Lipase } & $1454 \pm 95$ & CCK + secretin & Olive oil emulsion, $\mathrm{pH} 9,25^{\circ} \mathrm{Cm}$ & $42-46 y r, n=38$, Palasciano $^{41}$ \\
\hline & $839 \pm 429$ & Baseline & Olive oil emulsion, $\mathrm{pH} 9,25^{\circ} \mathrm{Cm}$ & $20-55 y r, n=7$, Mott $^{43}$ \\
\hline & $74-1674$ & Test meal ${ }^{c}$ & Olive oil emulsion, $\mathrm{pH} 9.1,37^{\circ} \mathrm{Cm}$ & nd, $n=15$, Braganza $^{7}$ \\
\hline & $84-1127$ & Baseline & Tributyrin, $\mathrm{pH} 8,25^{\circ} \mathrm{C}$ & $22-36 y r, n=7$, Fredrikzon ${ }^{24}$ \\
\hline & $750-1125$ & Test meal ${ }^{\mathrm{d}}$ & Tributyrin, $\mathrm{pH} 8,25^{\circ} \mathrm{C}$ & $22-36 y r, n=7$, Fredrikzon ${ }^{24}$ \\
\hline & $1200 \pm 459$ & $\mathrm{CCK}+$ cerulein $(\mathrm{PPJ})^{*}$ & Olive oil emulsion, $\mathrm{pH} 9,25^{\circ} \mathrm{Cm}$ & 29-58 yr, n = 7, Escourrou ${ }^{8}$ \\
\hline & $977 \pm 282$ & CCK + cerulein & Olive oil emulsion, $\mathrm{pH} 9,25^{\circ} \mathrm{C}^{\mathrm{m}}$ & $29-58 \mathrm{yr}, \mathrm{n}=7$, Escourrou ${ }^{8}$ \\
\hline & $|969 \pm 24|$ & Test meal ${ }^{\mathrm{e}}$ & Olive oil emulsion, $\mathrm{pH} 9,25^{\circ} \mathrm{C}^{\mathrm{m}}$ & $20-28$ yr, $n=26$, Bozkurt $^{44}$ \\
\hline & $1020 \pm 128$ & $\mathrm{CCK}+$ secretin & Olive oil emulsion, $\mathrm{pH} 9.1,37^{\circ} \mathrm{Cm}$ & $25-7 \mid \mathrm{yr}, \mathrm{n}=15$, Moreau $^{40}$ \\
\hline & $200-2400$ & Test meal ${ }^{f}$ & Tributyrin, $\mathrm{pH} 8.0,37^{\circ} \mathrm{C}$ & $22-42$ yr, $n=15$, Carrière ${ }^{34}$ \\
\hline & $600-1400$ & Test meal ${ }^{g}$ & Triolein emulsion, $\mathrm{pH} 9.0,37^{\circ} \mathrm{C}^{\mathrm{P}}$ & 19-24 yr, $\mathrm{n}=7$, Armand $^{29}$ \\
\hline & $200-1000$ & Test meal ${ }^{\mathrm{h}}$ & Tributyrin, $\mathrm{pH} 7.5,27^{\circ} \mathrm{C}$ & $38-58 \mathrm{yr}, \mathrm{n}=18, \mathrm{Yago}^{36}$ \\
\hline & $772,000 \pm 200,000 / 240 \mathrm{~min}$ & Test meali & Olive oil emulsion, $\mathrm{pH} 8.8,30^{\circ} \mathrm{C} q$ & $22-40 y r, n=6$, Schwizer ${ }^{31}$ \\
\hline & $1105 \pm 360$ & Baseline & Triolein emulsion, $\mathrm{pH} 9,25^{\circ} \mathrm{C}$ & $22-26$ yr, $\mathrm{n}=14$, Keller $^{39}$ \\
\hline & $4740 \pm 800$ & Test meali & Triolein emulsion, $\mathrm{pH} 9,25^{\circ} \mathrm{C}$ & $22-26$ yr, $n=14$, Keller $^{39}$ \\
\hline & $1500-4000$ & Test mealk & Tributyrin, $\mathrm{pH} 8.0,37^{\circ} \mathrm{C}$ & $22-26$ yr, $n=8$, Armand $^{30}$ \\
\hline & $2000-7000$ & Test meal' & Tributyrin, $\mathrm{pH} 8.0,37^{\circ} \mathrm{C}$ & $2 \mathrm{I}-25 \mathrm{yr}, \mathrm{n}=6$, Carrière ${ }^{35}$ \\
\hline \multirow[t]{2}{*}{ CEL } & $3.9-29.5$ & Baseline & p-nitrophenyl acetate, $\mathrm{pH} 7.4$ & $22-36 y r, n=7$, Fredrikzon ${ }^{24}$ \\
\hline & $10-15$ & Test meal ${ }^{\mathrm{d}}$ & p-nitrophenyl acetate, $\mathrm{pH} 7.4$ & $22-36 y r, n=7$, Fredrikzon ${ }^{24}$ \\
\hline Phospholipase & $24.44 \pm 1.53$ & CCK + secretin & Egg-yolk lipoprotein, $\mathrm{pH} 8,40^{\circ} \mathrm{C}$ & $42-46 y r, n=38$, Palasciano ${ }^{41}$ \\
\hline \multirow[t]{2}{*}{ Trypsin } & $13-138$ & Test mealc & TAME, $\mathrm{pH} 7.7,37^{\circ} \mathrm{C}$ & nd, $n=15$, Braganza $^{7}$ \\
\hline & $25-50$ & Test meal ${ }^{\mathrm{h}}$ & BAEE, $\mathrm{pH} 7.9,27^{\circ} \mathrm{C}$ & $38-58 \mathrm{yr}, \mathrm{n}=18, \mathrm{Yago}^{36}$ \\
\hline \multirow[t]{2}{*}{ Chymotrypsin } & $147 \pm 1 \mid$ & $\mathrm{CCK}+$ secretin & ATEE, $\mathrm{pH} 7.9,25^{\circ} \mathrm{C}$ & $42-46 \mathrm{yr}, \mathrm{n}=38$, Palasciano $1979^{41}$ \\
\hline & $65 \pm 17$ & Baseline & ATEE, $\mathrm{pH} 7.9,25^{\circ} \mathrm{C}$ & $20-55 \mathrm{yr}, \mathrm{n}=7$, Mott $^{43}$ \\
\hline
\end{tabular}


Table 2 (Continued)

\begin{tabular}{|c|c|c|c|c|}
\hline & Activity (Units) ${ }^{\mathbf{b}}$ & Collection condition & Method of measurement & Age, number, references \\
\hline \multirow{9}{*}{ Amylase } & $113 \pm 56$ & CCK + cerulein (PPJ)* & ATEE, $\mathrm{pH} 7.9,25^{\circ} \mathrm{C}$ & $29-58$ yr, n $=7$, Escourrou ${ }^{8}$ \\
\hline & $109 \pm 30$ & CCK + cerulein & ATEE, $\mathrm{pH} 7.9,25^{\circ} \mathrm{C}$ & $29-58$ yr, $n=7$, Escourrou ${ }^{8}$ \\
\hline & $30-100$ & Test meal' & ATEE, $\mathrm{pH} 7.5,37^{\circ} \mathrm{C}$ & $2 \mathrm{I}-25 \mathrm{yr}, \mathrm{n}=6$, Carrière ${ }^{35}$ \\
\hline & $50-75$ & Test meal $^{\mathrm{h}}$ & ATEE, $\mathrm{pH} 7.9,27^{\circ} \mathrm{C}$ & $38-58$ yr, $n=18, Y_{a g o}^{36}$ \\
\hline & $31-840$ & Test meal ${ }^{c}$ & Starch, $\mathrm{pH} 7,30^{\circ} \mathrm{C}$ & $\mathrm{nd}, \mathrm{n}=15$, Braganza $^{7}$ \\
\hline & $161 \pm 68$ & CCK + cerulein (PPJ)* & Starch & $29-58$ yr, n $=7$, Escourrou ${ }^{8}$ \\
\hline & $143 \pm 36$ & CCK + cerulein & Starch & $29-58$ yr, $n=7$, Escourrou ${ }^{8}$ \\
\hline & $1.5-4.2$ & Test meal ${ }^{h}$ & Starch, pH 6.9 & $38-58 \mathrm{yr}, \mathrm{n}=18$, Yago $^{36}$ \\
\hline & $2.5-16$ & Test meal' & Starch, $\mathrm{pH} 6.9,30^{\circ} \mathrm{C}$ & $2 \mathrm{I}-25 \mathrm{yr}, \mathrm{n}=6$, Carrière $\mathrm{e}^{35}$ \\
\hline
\end{tabular}

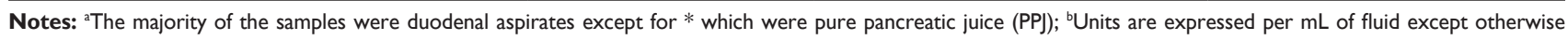
indicated. I IU of lipase activity corresponds to I $\mu$ mole free fatty acid released/min; I U of phospholipase activity corresponds to I NaOH $\mu$ equivalent liberated/min; I IU of CEL activity corresponds to I $\mu \mathrm{mol}$ p-nitrophenol produced/minute; I IU of amylase activity corresponds to I $\mu$ mole of maltose equivalent released/min; I IU of trypsin activity corresponds to I $\mu$ mole of substrate hydrolyzed/min or ${ }^{n} \mathrm{I} U$ corresponds to I $\mu \mathrm{g} / \mathrm{ml}$ or ${ }^{\circ} \mathrm{I} U$ corresponds to I nanomol of $p$-nitroaniline produced/min; I IU of chymotrypsin activity corresponds to I $\mu$ mole of substrate hydrolyzed/min; For lipase activity measurement the authors used also different concentration and type of bile salts that was not reported in the "Method of measurement". Test meals: 'Lundh Borgström test meal (500 mL, 5\% proteins [P], 6\% lipids [L], I5\% carbohydrates [C]); ${ }^{\mathrm{d} T e s t ~ m e a l ~(450-850 ~ m L ~}$

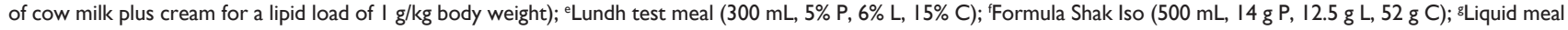
( $400 \mathrm{~mL}$, I egg, I egg white, $70 \mathrm{~g}$ olive oil, $70 \mathrm{~g}$ sucrose); 'Liquid meal (200 mL, $8.5 \mathrm{~g} \mathrm{P,} 7 \mathrm{~g} \mathrm{~L}, 26.5 \mathrm{~g} \mathrm{C})$; 'Formula $10 \%$ Intralipid (500 mL, 550 kcal); 'Formula ( $300 \mathrm{~mL}$, I I g P, $10 \mathrm{~g} \mathrm{~L}, 4 \mathrm{I} \mathrm{g} \mathrm{C);}{ }^{*}$ Formula ( $500 \mathrm{~mL}, 34 \mathrm{~g} \mathrm{P,} 50 \mathrm{~g} \mathrm{~L}, 50 \mathrm{~g} \mathrm{C}$ ); 'Mixed solid/liquid meal (700 mL, $80 \mathrm{~g}$ string beans, $90 \mathrm{~g}$ beef meat, $70 \mathrm{~g}$ fried potatoes, $10 \mathrm{~g}$ butter, I5 mL olive oil);

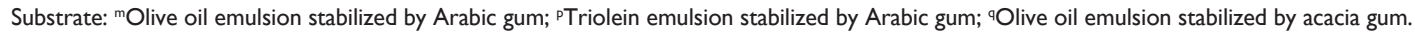

Abbreviations: ATEE, N-acetyl-L-tyrosine ethyl ester; BAEE, N-benzoyl-L-arginine ethyl ester; BAPNA, benzoyl-DL-arginine-p-nitroaniline; BTEE, N-benzoyl-DL-tyrosine ethyl acetate ester; CEL, carboxyl ester lipase; CCK, cholecystokinin; TAME, p-toluene sulfonyl-L-arginine methyl ester; PPJ, pure pancreatic juice.

Table 3 Postprandial output expressed as amount of the main pancreatic enzymes in the duodenal lumen in healthy adult humans ${ }^{\mathrm{a}}$

\begin{tabular}{|c|c|c|c|c|}
\hline & Output $^{b}$ & Collection condition & Method of measurement & Age, number, references \\
\hline \multirow[t]{7}{*}{ Lipase } & $54.9 \pm 10.7^{c, d}$ & Liquid test meal ${ }^{\mathrm{h}}$ & Tributyrin, $\mathrm{pH} 8.0,37^{\circ} \mathrm{C}$ & $22-42 y r, n=15$, Carrière $^{34}$ \\
\hline & $88.2 \pm 25^{c, d}$ & Liquid test meal ${ }^{\mathrm{h}}$ & Tributyrin, $\mathrm{pH} 8.0,37^{\circ} \mathrm{C}$ & $22-42 \mathrm{yr}, \mathrm{n}=15$, Carrière $^{34}$ \\
\hline & $245 \pm 22^{\mathrm{c}, \mathrm{e}}$ & Liquid test meali & Triolein emulsion, $\mathrm{pH} 8.0$ & $23-30 \mathrm{yr}, \mathrm{n}=6$, Borovicka ${ }^{33}$ \\
\hline & $442 \pm 87^{\mathrm{d}, \mathrm{f}}$ & Liquid test meali & Enzyme immunoassay & $22-40 y r, n=6$, Schwizer $^{31}$ \\
\hline & $253 \pm 95^{g}$ & Liquid test meal ${ }^{\mathrm{k}}$ & ELISA & $20-50$ yr, $n=3$, Carrière $\mathrm{e}^{38}$ \\
\hline & $203 \pm 96^{g}$ & Liquid/solid test meal' & ELISA & $20-50$ yr, $\mathrm{n}=7$, Carrière ${ }^{38}$ \\
\hline & $416 \pm 142^{c, e}$ & Liquid/solid test meal $^{\mathrm{m}}$ & Tributyrin, pH 8.0 & $2 \mathrm{I}-25 \mathrm{yr}, \mathrm{n}=6$, Carrière ${ }^{35}$ \\
\hline Chymotrypsin & $133 \pm 50^{c, e}$ & Liquid/solid test meal ${ }^{\mathrm{m}}$ & ATEE, $\mathrm{pH} 7.5,37^{\circ} \mathrm{C}$ & $21-25$ yr, $n=6$, Carrière $\mathrm{e}^{35}$ \\
\hline Amylase & $167 \pm 133^{\mathrm{c}, \mathrm{e}}$ & Liquid/solid test meal ${ }^{\mathrm{m}}$ & Starch, $\mathrm{pH} 6.9,30^{\circ} \mathrm{C}$ & $2 \mathrm{I}-25 \mathrm{yr}, \mathrm{n}=6$, Carrière $\mathrm{e}^{35}$ \\
\hline
\end{tabular}

Notes: aSamples are duodenal aspirates; ' $\mathrm{O}$ utput is expressed as total $\mathrm{mg}$ of proteins measured by immunoassay or specific ELISA test or cestimated using the known specific activity of enzymes (for pure human pancreatic lipase $8000 \mathrm{IU} / \mathrm{mg}$ on tributyrin or $1785 \mathrm{lU} / \mathrm{mg}$ on triolein), and for ${ }^{\mathrm{d}} \mathrm{I}-\mathrm{h}$ period, e3-h period, ${ }^{\mathrm{f}} 4$-h period, 890 -min period; For lipase activity measurement the authors also used a different concentration and type of bile salts that was not reported in the "Method of measurement." Test meals: hFormula Shak Iso (500 mL, $14 \mathrm{~g}$ proteins [P], I $2.5 \mathrm{~g}$ lipids [L], $52 \mathrm{~g}$ carbohydrates [C]); 'Formula Ensure (500 mL, I $6.8 \mathrm{~g} \mathrm{P,} \mathrm{I} 3.4 \mathrm{~g} \mathrm{~L}, 53.4 \mathrm{~g} \mathrm{C})$; i Formula I0\% Intralipid (500 mL, 550 kcal); kFormula Shak Iso (500 mL, $19 \mathrm{~g} \mathrm{P}, 17 \mathrm{~g} \mathrm{~L}, 69 \mathrm{~g} \mathrm{G})$; 'mixed solid/liquid meal (700 mL, $80 \mathrm{~g}$ string beans, $90 \mathrm{~g}$ beef meat, $70 \mathrm{~g}$ French fries, $10 \mathrm{~g}$ butter); ${ }^{2}$ Mixed solid/liquid meal ( $700 \mathrm{~mL}, 80 \mathrm{~g}$ string beans, $90 \mathrm{~g}$ beef meat, $70 \mathrm{~g}$ fried potatoes, $10 \mathrm{~g}$ butter, $15 \mathrm{~mL}$ olive oil).

Abbreviations: ATEE, N-acetyl-L-tyrosine ethyl ester; ELISA, enzyme-linked immunosorbent assay.

During the intestinal phase, enterohormones, such as CCK, together with neurotransmitters and neuropeptides further stimulate pancreatic secretion. ${ }^{49,54}$ Thus, digestive pancreatic enzyme response to a meal follows a specific pattern in which the degree and duration depend on nutrient composition, caloric content, and physical properties of the meal through hormonal and neural regulations; enzyme secretion into the duodenum increases quickly reaching peak output within the first 20 to 60 minutes postprandially, then decreasing to a stable level before reaching an interdigestive level at the end of the digestive period, ie, about 4 hours after meal intake. $^{27}$

\section{Role of pancreatic enzymes in lipid bioavailability}

Pancreatic juice plays a key role in the digestion of all macronutrients, but is most crucial for lipid digestion. Protein digestion begins in the stomach with the concomitant action of hydrochloric acid and pepsin, continues with pancreatic proteases in the duodenum, and finishes with numerous brush border peptidases located all over the small intestine..$^{50}$ Starch digestion begins in the mouth with salivary amylase, continues with pancreatic amylase, and ends with several intestinal brush border oligosaccharidases..$^{50}$ In contrast, the majority of lipid digestion and absorption occurs between 
the pylorus and the ligament of Treitz. Prior to this step, 5\% to $40 \%$ of the dietary triglyceride acyl chains are released in the stomach by gastric lipase, ${ }^{29,30,34,51,55,56}$ which continues its action in the duodenum together with pancreatic lipase until these enzymes are degraded by pancreatic proteases. ${ }^{34}$ The human pancreatic lipase (HPL) specifically cleaves the outer sn- 1 and sn-3 esters on the triglyceride molecules and generates two free fatty acids and a 2-monoglyceride. ${ }^{10,19}$ This lipase needs a specific cofactor, colipase, to anchor at the lipid-droplet surface containing phospholipids and surrounded by bile lipids (bile salts and phospholipids). ${ }^{16,58}$ Although a $\mathrm{pH}$ of 8 to 9 appears to be optimal for this lipase activity in vitro, bile salts allow the enzyme to work efficiently at a $\mathrm{pH}$ of 6 to 6.5 in vivo. ${ }^{10,29,35} \mathrm{HPL}$ is responsible for the hydrolysis of $40 \%$ to $70 \%$ of triglycerides. ${ }^{29,30,34}$ The pancreatic lipase related 1 protein (hPLRP1) has no known lipolytic activity ${ }^{11,12,16}$ but inhibits to some extent lipolysis of milk triglycerides by HPL. ${ }^{9}$ The pancreatic lipase-related 2 protein (hPLRP2) exhibits a broad substrate specificity hydrolyzing milk triglycerides in a synergistic effect with HPL, ${ }^{9}$ phospholipids, ${ }^{15,16,19}$ galactolipids, ${ }^{13,18}$ and esters of lipid-soluble vitamins. ${ }^{17}$ Carboxyl ester lipase (CEL) (also secreted by mammary gland cells as bile salt-stimulated lipase, (BSSL)) will hydrolyze triglycerides, diglycerides, phospholipids, and esters of lipid-soluble vitamins and of cholesterol. ${ }^{14}$ Of note, hPLRP2, which is highly expressed in early life, plays an important role in lipid digestion in infants fed human milk, ${ }^{59,60}$ along with BSSL. ${ }^{59}$ Phospholipase A2 hydrolyzes phospholipids to lysophospholipids ${ }^{20}$ which is essential for an optimal absorption of lipid nutrients. ${ }^{61}$ Products generated during lipolysis are solubilized in bile salts-mixed micelles and liposomes (vesicles) which allow absorption across the intestinal villi. ${ }^{62}$ Once absorbed, the digested lipids are converted back to triglycerides, phospholipids, and esters of cholesterol and of lipid-soluble vitamins, then packaged as chylomicrons and transported through the thoracic duct into the systemic circulation for delivery to various sites throughout the body. ${ }^{61,63}$

\section{Exocrine pancreatic insufficiency Clinical presentation and diagnosis}

Exocrine pancreatic insufficiency (EPI) is largely a clinical diagnosis. A patient with a known cause of pancreatic insufficiency who presents with weight loss and fatty diarrhea is usually begun on treatment without extensive testing. As up to $20 \%$ of patients with chronic pancreatitis resulting in insufficiency will present with no history of pain suggestive of pancreatitis, steatorrhea may be the presenting complaint. ${ }^{64}$
The diagnostic options include indirect measures (ie, 72-hour fecal fat and fecal elastase) or direct measures (ie, secretincerulein or secretin-pancreozymin tests). Steatorrhea is classically defined as at least $7 \mathrm{~g}$ of fecal fat over 24 hours, in the context of a 72-hour stool test while on $100 \mathrm{~g}$ of fat daily, ${ }^{65}$ however, quantification of fecal fat is inconvenient and difficult. With reasonable clinical suspicion, a positive spot stool test may be adequate to detect steatorrhea ${ }^{66}$ but will not allow monitoring of response to therapy. Fecal elastase testing may be used to demonstrate a lack of endogenous enzyme. It has been found that fecal elastase is $72 \%$ sensitive for severe pancreatic insufficiency and $90 \%$ specific. It does have lower sensitivity with milder steatorrhea, and is not as useful in diabetics, as fecal elastase decreases with increased duration of diabetes. ${ }^{67-69}$ In contrast to the above indirect measurements of pancreatic function, direct measurements with the secretin-cerulein or secretin-pancreozymin tests are the gold standard for accurate assessment of the exocrine function of the pancreas. ${ }^{69,70}$ However, the limitations of the direct functional tests are that they are usually performed only at specialized centers, and they are time consuming and expensive. ${ }^{69}$

Patients usually will present for evaluation when $<10 \%$ of exocrine pancreatic function remains, which results in lipid malabsorption. ${ }^{3,71}$ Steatorrhea (frothy, foul smelling, buoyant stools), weight loss, abdominal discomfort, and abdominal swelling are the common presenting symptoms and are related to the inadequate lipid digestion. Even with significant pancreatic insufficiency, protein and starch digestion are usually maintained at a normal physiologic level. However, once pancreatic insufficiency progresses, lipid malabsorption becomes the overriding problem and cause of many of the clinical symptoms and nutritional deficiencies. Consequences of abnormal lipid digestion lead to malnutrition, with malabsorption of lipid-soluble vitamins (A, D, E, K), depleted micronutrients, and decreased circulating lipoproteins. . $^{3,72-74}$ Exocrine pancreatic insufficiency itself can cause or exacerbate motility disorders. There are alterations in neurohormonal regulation in gastrointestinal motility; specifically, the production of CCK and of pancreatic polypeptide are adversely affected by undigested food in the intestines, which can lead to rapid gastric emptying and altered antroduodenal and gallbladder motility. In untreated EPI, patients are noted to have shorter fed patterns, and a faster small intestinal transit that is largely reversed with enzyme therapy. ${ }^{71}$ The severity of such motility disorders is often related to the severity of the pancreatic insufficiency, and this can often be corrected with enzyme replacement therapy. ${ }^{75-80}$ 


\section{Causes of lipid maldigestion and malabsorption}

There are various causes of pancreatic insufficiency resulting in malabsorption (Table 4), and for some the status of pancreatic enzyme levels has been documented (Table 5). ${ }^{23,24,35,40,42,44,45,71}$ Chronic pancreatitis (CP) and cystic fibrosis (CF) are the most common causes of irreversible pancreatic insufficiency. Diabetes may also result in exocrine insufficiency. ${ }^{81}$ In contrast, decreased production of pancreatic lipase without glandular destruction is associated with Celiac sprue, Crohn's disease, and Shwachman-Diamond syndrome., ${ }^{2,71}$ Reversible pancreatic insufficiency has been reported in premature infants due to developmental immaturity. ${ }^{22-25}$ The pancreas will gain complete function in infants at 2 years of age. ${ }^{22}$ Other causes of lipid maldigestion are blockage of the pancreatic duct, and surgical resection. . $^{2,71}$

Motility disorders that result in rapid gastric emptying and decreased small intestinal transit time may also be associated with malabsorption due to inadequate lipid digestion. Rapid transit causes poor mixing of food together with bile and pancreatic enzymes, further reduces contact time with the small intestine leading to impaired digestion and absorption, and affects the stimulation of pancreatic function. ${ }^{5,71}$ For instance, gastrectomy alters gastric emptying, which reduces lipase production because chyme rapidly bypasses the duodenum resulting in reduced stimulation of duodenal hormones that normally stimulate the pancreas to release enzymes. ${ }^{5}$ Of note, some studies of steatorrhea after gastrectomy have not demonstrated a benefit of pancreatic enzyme supplementation. ${ }^{82}$

It is also important to be aware that diabetic patients may also suffer from exocrine insufficiency as a result of endocrine failure, presenting as either classic steatorrhea or more subtly as brittle diabetes. ${ }^{81}$ Studies have reported that exocrine dysfunction occurs in up to $43 \%$ of insulindependent diabetics, but its severity is typically mild to moderate, and only $1 \%$ of these patients require therapy. ${ }^{83,84}$ Mild to moderate exocrine insufficiency was reported in $30 \%$ of type 2 diabetics, $19 \%$ of whom were suffering from severe insufficiency. ${ }^{85}$ These studies raised the question of the clinical significance of EPI in diabetic patients, which would potentially raise health care costs to these patients if expensive enzyme replacement therapy were required. A thorough investigation studied pancreatic function in type 1 diabetic patients with a secretin-cerulein test, fecal fat stimulation, and 2 fecal elastase tests to determine the accuracy of previous studies and define the clinical significance. In this study, 33\% of type 1 diabetics were found to have mild to moderate pancreatic insufficiency, but none of the patients had lipase levels $<10 \%$ of normal, which would necessitate enzyme replacement. It was concluded that fecal elastase or fecal fat levels were not reliable diagnostic tools for diabetes. Moreover, the majority of these patients had steatorrhea not related to pancreatic function, but rather to bacterial overgrowth. ${ }^{69}$ Although diarrhea and steatorrhea are often multifactorial in diabetics, and the significance of exocrine insufficiency in diabetics is still under study, physicians should be aware of the association and have a low threshold to test for this entity in diabetics. ${ }^{81}$

\section{The pathophysiology of EPI caused by glandular destruction in $\mathrm{CP}$ and $\mathrm{CF}$}

Irreversible pancreatic insufficiency is mainly observed in $\mathrm{CP}$ and $\mathrm{CF}^{4,5}$ In $\mathrm{CP}$, long-standing inflammation with fibrosis results in destruction of acinar cells. A variety of proposed pathogenic mechanisms has been described. Alcohol is a common cause of chronic pancreatitis, and it has been shown to be directly toxic to the pancreatic acinar cells. It produces cytoplasmic lipid accumulation ultimately leading to fibrosis and gland failure. ${ }^{57}$ Moreover, chronic use of alcohol can cause pancreatic secretions to be more lithogenic, which results in stone formation and pancreatic duct obstruction. The contact of stones with the duct lumen will ultimately lead to a cascade of events, which includes ulceration, scarring, stasis, further stone formation with eventual atrophy, and fibrosis. ${ }^{86,87}$ In contrast to de novo stone formation as a result of alcohol consumption, repeated attacks of acute pancreatitis from various causes including alcohol will result in peri-ductular scarring, which leads to duct obstruction

Table 4 Etiologies of exocrine pancreatic insufficiency

\begin{tabular}{ll}
\hline Mechanism & Etiology \\
\hline Decreased lipase production and delivery, increase lipase destruction & Chronic pancreatitis, cystic fibrosis, diabetes \\
Pancreatic duct obstruction & Periampullary tumor, pancreatic head cancer, IPMN, benign tumors \\
Decreased endogenous lipase stimulation and production & Celiac disease, Crohn's disease, Shwachman-Diamond syndrome \\
$\begin{array}{l}\text { Motility disorders (decrease contact time, interaction with chyme, } \\
\text { decrease stimulation of pancreatic enzymes) }\end{array}$ & Gastrectomy, gastric bypass, extensive small bowel resection
\end{tabular}

Abbreviation: IPMN, intraductal papillary mucinous neoplasm. 
Table 5 Baseline or postprandial activity of the main pancreatic enzymes in transitory or irreversible pancreatic insufficiency ${ }^{a}$

\begin{tabular}{|c|c|c|c|c|}
\hline & Activity (Units) ${ }^{b}$ & Collection condition & Method of measurement & Age, number, references \\
\hline \multicolumn{5}{|l|}{ Preterm infants } \\
\hline \multirow[t]{4}{*}{ Lipase } & $378(|45-||2|)$ & CCK + secretin & Olive oil emulsion, $\mathrm{pH} 9.1,37^{\circ} \mathrm{C}^{f}$ & 32-34 wk GA, n = 36, Zoppi ${ }^{23}$ \\
\hline & |49-586 & Baseline & Tributyrin, $\mathrm{pH} 8,25^{\circ} \mathrm{C}$ & $16-38 \mathrm{~d}, \mathrm{n}=7$, Fredrikzon ${ }^{24}$ \\
\hline & $50-100$ & Test meal ${ }^{c}$ & Tributyrin, $\mathrm{pH} 8,25^{\circ} \mathrm{C}$ & $16-38 d, n=7$, Fredrikzon ${ }^{24}$ \\
\hline & $8.4-15.1$ & Baseline & Triolein, $\mathrm{pH} 7.4$ & $23-26 d, n=35, B^{2}{ }^{42}$ \\
\hline \multirow[t]{2}{*}{ CEL } & $12.2-32.9$ & Baseline & p-nitrophenyl acetate, $\mathrm{pH} 7.4$ & $16-38 \mathrm{~d}, \mathrm{n}=7$, Fredrikzon ${ }^{24}$ \\
\hline & $2.5-9$ & Test meal ${ }^{\mathrm{c}}$ & p-nitrophenyl acetate, $\mathrm{pH} 7.4$ & $16-38 \mathrm{~d}, \mathrm{n}=7$, Fredrikzon ${ }^{24}$ \\
\hline \multirow[t]{2}{*}{ Trypsin } & $292(0-682)$ & $\mathrm{CCK}+$ secretin & BAEE, $\mathrm{pH} 8,25^{\circ} \mathrm{C}$ & 32-34 wk GA, n = 36, Zoppi ${ }^{23}$ \\
\hline & $5.2-8.6$ & Baseline & TAME, pH 8.1 & $23-26 \mathrm{~d}, \mathrm{n}=35$, Boehm $^{42}$ \\
\hline Amylase & $4.3(0-5.1)$ & $\mathrm{CCK}+$ secretin & Starch, $\mathrm{pH} 6.9,25^{\circ} \mathrm{C}$ & 32-34 wk GA, n = 36, Zoppi ${ }^{23}$ \\
\hline \multicolumn{5}{|l|}{ CF infants } \\
\hline Lipase & $7 \pm 3$ & CCK + secretin & Olive oil emulsion, $\mathrm{pH} 9.1,37^{\circ} \mathrm{C}^{f}$ & $\mathrm{I}-30 \mathrm{mo}, \mathrm{n}=6$, Moreau $^{40}$ \\
\hline (PS) & $6300-28,200 \mathrm{IU} / \mathrm{kg} / \mathrm{h}$ & $\mathrm{CCK}+$ secretin & Tributyrin, $\mathrm{pH} 8.5,37^{\circ} \mathrm{C}$ & $0.5-17 \mathrm{yr}, \mathrm{n}=5$, Nouri $^{45}$ \\
\hline (PI) & 0 & $\mathrm{CCK}+$ secretin & Tributyrin, $\mathrm{pH} 8.5,37^{\circ} \mathrm{C}$ & $12-13 y r, n=2$, Nouri $^{45}$ \\
\hline Phospholipase (PS) & $25-33 \mathrm{mmol} / \mathrm{kg} / \mathrm{h}$ & CCK + secretin & ${ }^{31} \mathrm{P}$ NMR spectra, $\mathrm{pH} 7.44,37^{\circ} \mathrm{C}$ & $0.5-17 \mathrm{yr}, \mathrm{n}=5$, Nouri ${ }^{45}$ \\
\hline (PI) & 0 & $\mathrm{CCK}+$ secretin & ${ }^{31} \mathrm{P}$ NMR spectra, $\mathrm{pH} 7.44,37^{\circ} \mathrm{C}$ & $12-13 y r, n=2$, Nouri $^{45}$ \\
\hline \multicolumn{5}{|l|}{ Adult Mild-EPI } \\
\hline \multirow[t]{2}{*}{ Lipase } & $458 \pm 83$ & Test meal $^{\mathrm{d}}$ & Olive oil emulsion, $\mathrm{pH} 9,25^{\circ} \mathrm{C}^{f}$ & $21-73 y r, n=15$, Bozkurt ${ }^{44}$ \\
\hline & $2000-6000$ & Test meal ${ }^{\mathrm{e}}$ & Tributyrin, $\mathrm{pH} 8.0,37^{\circ} \mathrm{C}$ & $40-60 \mathrm{yr}, \mathrm{n}=5$, Carrière ${ }^{35}$ \\
\hline \multicolumn{5}{|l|}{ Adult Severe-EPI } \\
\hline \multirow[t]{3}{*}{ Lipase } & $52 \pm 31$ & Test meal ${ }^{d}$ & Olive oil emulsion, $\mathrm{pH} 9,25^{\circ} \mathrm{C}^{f}$ & $21-73 y r, n=18$, Bozkurt $^{44}$ \\
\hline & $480 \pm 125$ & CCK + secretin & Olive oil emulsion, $\mathrm{pH} 9.1,37^{\circ} \mathrm{C}^{f}$ & $16-72 y r, n=13$, Moreau $^{40}$ \\
\hline & 160 & Test meal ${ }^{\mathrm{e}}$ & Tributyrin, $\mathrm{pH} 8.0,37^{\circ} \mathrm{C}$ & $43-6 I$ yr, $n=7$, Carrière ${ }^{35}$ \\
\hline
\end{tabular}

Notes: aSamples are duodenal aspirates; bUnits are expressed per $\mathrm{mL}$ of fluid except otherwise indicated. I IU of lipase activity corresponds to I $\mu \mathrm{mole}$ free fatty acid released/min; I U of phospholipase activity is expressed as mmoles of lysophospatidylcholine produced/kg body weight in total volume of duodenal juice secreted for I hour; I IU of CEL activity corresponds to I $\mu \mathrm{mol}$ p-nitrophenol produced/min; I IU of amylase activity corresponds to I $\mu$ mole of maltose equivalent released/min; I IU of trypsin activity corresponds to I $\mu$ mole of substrate hydrolyzed/min (TAME) or I $U$ of trypsin activity corresponds to I $\mu \mathrm{g} / \mathrm{mL}$ (BAEE); For lipase activity measurement the authors used also different concentration and type of bile salts that was not reported in the "Method of measurement".

Test meals: 'Human milk; 'undh test meal ( $300 \mathrm{~mL}, 5 \%$ proteins [P], $6 \%$ lipids [L], $15 \%$ carbohydrates [C]); ${ }^{\circ}$ Mixed solid/liquid meal $(700 \mathrm{~mL}, 80 \mathrm{~g} \mathrm{string}$ beans, $90 \mathrm{~g}$ beef meat, $70 \mathrm{~g}$ fried potatoes, $10 \mathrm{~g}$ butter, $15 \mathrm{~mL}$ olive oil); 'Olive oil emulsion stabilized by Arabic gum.

Abbreviations: BAEE, N-benzoyl-L-arginine ethyl ester; CCK, cholecystokinin; CEL, carboxyl ester lipase; PI, pancreatic insufficient; PS, pancreatic sufficient; TAME, p-toluene sulfonyl-L-arginine methyl ester.

with stasis and a similar cascade of events that will lead to glandular fibrosis. ${ }^{88,89}$ Oxidized byproducts of metabolism are produced in the liver and secreted in bile, and it is proposed that this results in oxidative stress as the bile is refluxed into the pancreatic ducts. Oxidative stress has also been attributed to high levels of dietary lipids or alcohol..$^{90-92}$ Also described is an immunologic response that results in an attack on the ductal epithelium, an autoimmune-like reaction, resulting in scarring and fibrosis. ${ }^{93} \mathrm{~A}$ recently proposed theory, the SAPE (sentinel acute pancreatitis event) hypothesis, combines a number of the above-described pathogenic mechanisms leading to chronic pancreatitis. It suggests an initial event of acute pancreatitis that leads to an inflammatory response secondary to an insult such as alcohol or oxidative stress. If this insult is removed, tissue repair occurs. If the insult is not removed, proinflammatory cytokines activate pancreatic stellate cells resulting in chronic pancreatitis with fibrosis and tissue destruction. This ultimately leads to reduced secretion of adequate amounts of lipase, giving rise to pancreatic insufficiency. ${ }^{94,95}$
In CF, the mutation of the CFTR (cystic fibrosis transmembrane conductance regulator) protein results in abnormal sodium and chloride transport. Normally, luminal chloride is exchanged for bicarbonate, which allows for an alkaline environment within the lumen, allowing highly concentrated proteins to remain in the soluble state. With mutant CFTR protein, the net result is abnormally viscous secretions and an acidic lumen, resulting in ductal obstruction. Prolonged obstruction results in tissue destruction by retained proteolytic enzymes, fibrosis, fatty replacement, cyst formation, and eventual exocrine insufficiency.,36

The initial effect of acinar destruction is decreased pancreatic enzyme production (Table 5). However, lipid digestion can be maintained to reach an absorption rate of $20 \%$ to $80 \%$ due to the action of gastric lipase secreted by the fundic mucosa of the stomach $;{ }^{51}$ indeed this lipase output is normal or higher in CP and CF patients, ${ }^{35,51,97}$ and its action take place both in the stomach and in the duodenum, being favored by a low level of pancreatic proteases and low intraduodenal pH. ${ }^{51}$ But the lipolysis rate reached by the gastric lipase is 
not always sufficient to make up for the lack of pancreatic lipase. ${ }^{5}$ As continued glandular destruction occurs in CP and $\mathrm{CF}$, the ductules are affected causing inadequate bicarbonate production and resulting in an inability to neutralize acidic chyme. ${ }^{3}$ Along with decreased pancreatic bicarbonate secretion, gastric acid production is increased in certain conditions associated with pancreatic insufficiency, notably advanced $\mathrm{CP}$ and $\mathrm{CF}{ }^{5,35,97-100}$ Consequently the intraduodenal $\mathrm{pH}$ will be acidic ( 3 to 5$)^{35,98}$ and will lead to enzyme inactivation and bile salt denaturation. ${ }^{5,71,98}$ The bile salt pool is even more reduced by decreased enterohepatic circulation of bile secondary to impaired ileal mucosa absorption. ${ }^{101}$ As bile salts are required to solubilize the lipolytic products within the intestinal lumen, this process further impairs lipid digestion and absorption. ${ }^{3,61}$

\section{Pancreatic enzyme replacement therapy \\ Formulations and pharmacokinetics}

The goal of supplemental enzyme therapy in EPI is to minimize nutrient malabsorption, especially of lipids, and to do this it is important to achieve an adequate concentration of active pancreatic enzymes in the duodenum at the same time that food is delivered. ${ }^{3,71}$ Attempting to replicate this physiologic process requires resistance to gastric inactivation and delivery of active enzyme at the site where digestion is required, the duodenum. The composition and various formulations of pancreatin and pancrelipase affect their use and ability to deliver appropriate amounts of active enzyme to the duodenum. Pancreatin, a crude mixture, is derived from swine or ox pancreas, and each milligram contains no less than 2 USP (United States Pharmacopeia) units of lipase and 25 USP units of amylase and protease activity. Pancrelipase is obtained from swine pancreas and is a more concentrated and purified enzyme preparation. Each milligram contains no less than 24 USP units of lipase and 100 USP units of amylase and protease activity. Because of its higher enzyme content, pancrelipase formulations are favored over pancreatin preparations. ${ }^{3}$ A variety of delivery agents has been developed in attempts to increase resistance to destruction, and enable delivery to sites where lipid digestion is physiologic, ie, the duodenum. The uncoated formulations are susceptible to acidic breakdown in the stomach and are currently used largely in clinical practice to treat the pain of chronic pancreatitis and not malabsorption. ${ }^{102}$ Enteric-coated preparations were designed to avoid inactivation in the stomach, as the enzyme is protected from the acidic environment by the coating, and then dissolves in the duodenum when $\mathrm{pH}$ exceeds 5 to $5.5 .^{3} \mathrm{~A}$ wide range of polymers, natural (carboxylmethyl or succinate high amylose starch) or synthetic (methacrylate copolymers, polymer cellulose acetate phtalate, hydroxyl propyl methyl cellulose phtalate), with different $\mathrm{pH}$ sensitivity, have been examined as excipients to circumvent the gastric inactivation of enzymes and to control the timing and location of their release in enteric-coated preparations. ${ }^{103,104}$ They are supposed to allow uniform mixing in the stomach without releasing their content and timely delivery to the duodenum for digestion to proceed. But effective delivery and release are difficult to achieve because the $\mathrm{pH}$ in the stomach can fluctuate from 6, owing to the buffering capacity of the meal, down to 2 during the fed state, ${ }^{98}$ and the duodenal $\mathrm{pH}$ ranges from 4 to $6,{ }^{35,105}$ with high individual variability. In fact, dissolution characteristics of excipients are quite different in terms of optimum $\mathrm{pH}$ ( 5 or 5.8 for example) and time (49 to 71 minutes for the half-time of release). ${ }^{106-108}$ As a result, enteric-coated microspheres are not bioequivalent in vitro, and probably not in vivo, depending on the $\mathrm{pH}$ of the duodenal content. ${ }^{106-108}$

Early enteric-coated formulations did not empty into the duodenum as quickly as smaller food particles, impairing their ability to aid in digestion. Newer formulations use the enteric-coated microsphere technology that allows a smaller, yet stable delivery system. Studies have demonstrated that the size of the particles or the microspheres affect the delivery to the duodenum, and that particles of smaller size empty more quickly, with $1.4 \mathrm{~mm}$ being the optimal size. ${ }^{109}$ In theory, along with delivering adequate amounts of lipase to the duodenum at the same time as the ingested food, microsphere technology should allow more adequate mixture with the postprandial chyme. ${ }^{3}$ Studies of labeled capsules suggest that even with varying sizes of microspheres, the ingested lipid may enter the duodenum in advance of the pancreatic enzyme. When, where and at how much enzyme is released is not very well studied in humans. ${ }^{110}$ The new FDA rules in terms of pancreatic enzyme replacement therapy (PERT) have instructed companies to set up clinical trials in order to fill this gap. The results of recent studies of delivery of pancrelipase should be informative and could help to ameliorate coating materials (ClinicalTrials.gov NCT00676702, Pancrease MT, Johnson \& Johnson Pharmaceutical, NJ, USA; NCT00744250, Pancrecarb MS16, Digestive Care, PA, USA; NCT00559052, Viokase 16, Axcan Pharma, Canada).

Currently, the main formulations are immediate-release, enteric-coated microspheres and minimicrospheres, enteric-coated microtablets, and enteric-coated microspheres with a bicarbonate buffer. A comprehensive table of these 
medications has been summarized in other reviews., ${ }^{3,76}$ A major focus of regulation of these products has been on the active enzyme content and accuracy of packaging. While instability of the enzymes results in delivery medications that contain less than the packaged amount of enzyme, the practice of "overfilling" in an effort to address enzyme degradation may result in excess enzyme content, resulting in formulations that deliver inadequate or excess amounts of enzyme. In Europe, historically these products have been regulated, resulting in more standard enzyme content. In the United States, until recently, because of lack of stringent regulation, studies showed marked variation in the enzyme content of the various formulations, generic products being of greatest concern. ${ }^{111}$ The marketing of products containing pancreatic enzymes extracted from animal tissue preceded the creation of the FDA in 1938, so that these products were historically not regulated by the FDA. In 2004, in response to concerns FDA issued a statement requiring that all manufacturers of PERT submit New Drug Applications. Eventually, the FDA set a deadline of April 28, 2010 for approval of all pancreatic enzyme products, and at the time of submission of this article, only 3 pancrelipase preparations have been approved for use in the United States: ${ }^{112}$ Creon (Abbott, IL, USA), EUR-1008 or Zenpep (Eurand, Milan, Italy), and Pancreaze (Johnson \& Johnson, NJ, USA). All these formulations have been demonstrated to be safe and effective in improving lipid malabsorption and the symptoms of maldigestion. The most studied of the approved enzymes, Creon, is an enteric-coated formulation of pancrelipase delivered in the form of minimicrospheres. ${ }^{113-115}$ Zenpep is an enteric-coated bead preparation. ${ }^{116}$ To counteract the problem of non-uniform drug delivery raised by the FDA, this formulation of pancrelipase enteric-coated microtablet is manufactured with label-claimed lipase content being zero-overfilled. ${ }^{116}$ Clinical Phase III trials demonstrated an improvement in coefficient of fecal fat absorption (CFA) ( $88.3 \%$ vs $62.8 \%$ in placebo group) and lipid-soluble vitamin levels. ${ }^{116}$ Pancreaze is an enteric-coated microtablet. ${ }^{112}$

In Europe availability of preparations varies by country and they are regulated nationally and not by the European Medicines Agency. Many regulatory agencies provide information on their website and information on available enzyme preparations may be sought through the national regulatory agency, the pharmaceuticals, or pharmacy references. In products in which the enzyme content has been standardized, there is still a marked variability in particle size, release, and, for some, acid stability, which may result in differences in clinical effect. ${ }^{106,117,118}$

\section{Dosing and schedule of administration}

The typical indications for starting enzyme replacement therapy are progressive weight loss and steatorrhea, defined as at least 7 to $15 \mathrm{~g}$ of fecal fat per day, but there are no substantial data to support these guidelines. Since steatorrhea does not typically occur until $>90 \%$ of pancreatic lipase activity is lost, $10 \%$ enzyme activity is the initial goal for therapy. Dosing is adjusted based on the amount of lipase in the supplements, and the initial dose aims at supplying 40 to $60 \mathrm{IU} /$ minute of lipase activity within the duodenal lumen. To achieve this goal in adults, approximately 25,000 to $40,000 \mathrm{IU}$ of lipase is required to digest a typical meal, and about 5000 to 25,000 IU of lipase per snack. However, is not recommended to exceed 10,000 IU of lipase per $\mathrm{kg}$ of body weight per meal. ${ }^{3,5,71,76}$ Pediatric dosing is detailed in the products' respective package inserts. Ultimately 50,000, 100,000 and 150,000 IU of lipase per day will decrease steatorrhea by $45 \%$, $60 \%$, and $70 \%$, respectively. ${ }^{119}$ Ideally the correct amount of lipase should be divided and administered through the course of a meal or immediately after a meal, and dose adjustments made after several days to allow for sufficient time for the enzymes to work. ${ }^{5}$ A recent study compared three different administration schedules using enzyme replacement before meals, during meals, or after meals. It was found that lipid digestion was better when giving enzymes during or after meals, and patient preference did not differ. ${ }^{120}$ Currently, none of the approved enzyme supplements are specifically designed for administration via percutaneous gastrostomy tubes. In patients who cannot swallow large capsules, and infants, opening the capsules into a small amount of acidic food (ie, apple sauce) is an acceptable way to administer the medication.

\section{Monitoring therapy}

Currently there are no guidelines in clinical practice for monitoring the efficacy of enzyme replacement therapy and determining a need for dose adjustment. In research studies, a commonly used method to monitor therapy is the use of the CFA and coefficient of nitrogen absorption. The CFA uses a 72-hour stool collection comparing the amount of lipid ingested with that excreted. ${ }^{121-123}$ The cumbersome nature of stool studies limits their use in the outpatient setting. Commonly, determining the efficacy of therapy is performed by clinically assessing the patient's weight loss or gain and diarrhea. Unfortunately, clinical assessment correlates poorly with the patient's nutritional status. ${ }^{124,125}$ In a recent study, approximately two-thirds of the study subjects, when asymptomatic, had evidence of nutritional 
deficiencies as measured by retinol-binding protein, ferritin, and pre-albumin. The authors concluded that monitoring of weight loss and diarrhea is an inadequate measure of nutritional deficiencies in EPI. ${ }^{126}$ Various breath tests have been developed, using various substrates labeled with ${ }^{13} \mathrm{C}$ including mixed triglycerides, triolein, and cholesteryl octanoate. ${ }^{127-129}$ As an example, the ${ }^{13} \mathrm{C}$-labeled mixed triglyceride breath test uses a labeled substrate with two molecules of stearic acid and octanoic acid. Lipolysis is associated with measured release of labeled carbon dioxide. ${ }^{130}$ This test was shown to be accurate in estimating pancreatic exocrine function and has been shown to correlate with nutritional markers when estimating response to enzyme supplementation. ${ }^{131,132}$ Because stool collection is often time consuming and difficult, and breath tests are not readily available in all locations or fully validated as a clinical tool, following patients clinically is the common approach in determining the efficacy of PERT. As the degree of symptoms and symptom improvement do not always correlate with the patient's nutritional status, in the future we would hope for more clinically relevant and widely available tests to monitor therapy, most likely in the form of a breath test or a spot stool test. ${ }^{124-126}$

\section{Efficacy}

Although the efficacy of enzyme replacement therapy is presumed, the data are not as robust as one might hope. Although numerous studies have evaluated the response to treatment for outcomes such as steatorrhea and fecal fat, surprisingly few have studied improvement in nutritional status, even in weight gain. ${ }^{2,113-116,122,133}$ Enzyme supplements have been found to improve lipid malabsorption compared with placebo in numerous trials, for both adults and children younger than 7 years old..$^{2,113-116,122,133}$ They have also been shown to improve symptoms related to pancreatic insufficiency such as abdominal pain, flatulence, stool consistency, and improve overall global impression of disease symptoms. ${ }^{113}$ A systematic review of the randomized trials of PERT identified only two studies that evaluated weight as an outcome, and the difference was not significant. ${ }^{134}$ It has been reported that in patients who were considered to be on acceptable replacement therapy, with reduction in steatorrhea, markers of significant malnutrition still persisted as measured by retinol-binding protein, transferring, and prealbumin. ${ }^{126}$ In a prospective, non-placebo controlled study, this group has also reported that increasing enzyme therapy to normalize ${ }^{13} \mathrm{C}$-mixed triglyceride breath test did significantly improve key markers of nutritional status at 1 year. ${ }^{132}$ As such, although it is presumed, the reduction in stool fat achieved by PERT has not been proven by rigorous research to be correlated with a complete correction of nutritional deficiency in patients with pancreatic insufficiency, preventing our overall assessment of the efficacy of this therapy. In the future, demonstration of long-term outcomes would also be of interest.

\section{Safety and side effects}

In general, PERT is regarded as safe with few side effects, and adverse events are comparable to those with placebo. ${ }^{2}$ Supplemental enzymes act within the lumen of the intestine, and this is considered an intraluminal and not a systemic therapy. The most commonly reported side effects for recently approved enzymes are headache $(6 \%)$, dizziness $(6 \%)$, abdominal pain (9\%), and flatulence (www.micromedex.com). Historically, hyperuricemia, and hyperuricosuria, which leads to dysuria and uric acid crystaluria, have been reported in cystic fibrosis patients with older formulations. ${ }^{135}$ Folic acid deficiency has been associated with use of pancreatin extracts which may form insoluble complexes with folate. ${ }^{76}$ Irritation of the oral mucosa may be avoided by not chewing the medications, or mixing them in foods with a $\mathrm{pH}>4.5$ (package inserts). A theoretical risk exists of xenotic viral infections, although such cases have not been reported. As more concern is focused on the effect of pthalates, which are commonly present in the polymer coating, the impact of this component will likely be evaluated further. ${ }^{136}$ The most concerning adverse effect associated with enzyme replacement is fibrosing colonopathy, which has been described in cystic fibrosis patients receiving $>24,000$ IU of lipase/ $\mathrm{kg}$ daily. ${ }^{137,138}$ It results in submucosal collagen deposition with fibrosis and varying degrees of stricturing. Some studies suggest that the acid-resistant coating of enzyme preparations may be responsible for the fibrosing colonopathy, as it has also been demonstrated with other medications that use the same methacrylic copolymer coating. ${ }^{76,139-143}$ In addition, as these cases largely occurred with high-dose enzyme therapy ( $>50,000 \mathrm{IU} / \mathrm{kg}$ daily), limits are suggested for maximum dosage and delivery. Caution should be used when doses exceed $2500 \mathrm{IU} / \mathrm{kg}$ per meal. Most formulations are considered pregnancy class $\mathrm{C}$, as there are insufficient data to evaluate their safety, and no data are available on their secretion in breast milk.

\section{Treatment failure}

Despite optimal dosing of enzymes and clinical assessment, treatment failures are common. A systematic approach is beneficial in determining the reason for treatment failure (Figure 1). The first step is to assess compliance, diet, and 


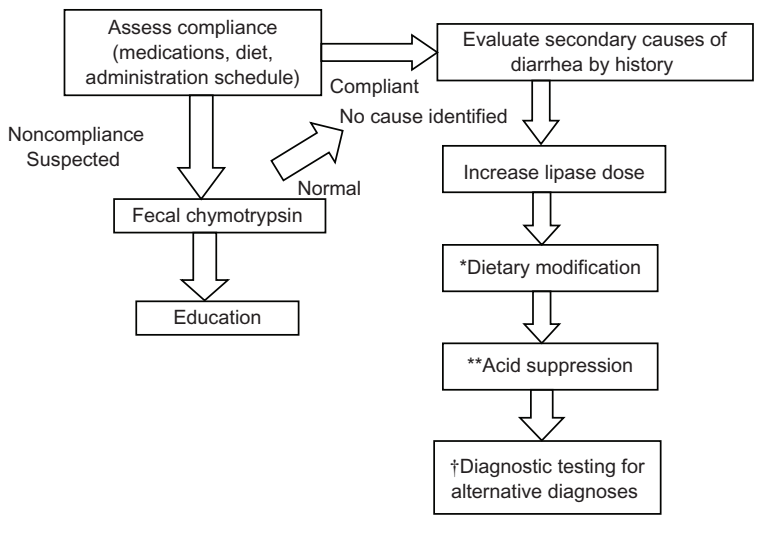

Figure I Failure of pancreatic enzyme therapy: a systematic approach. Notes: *Restrict fat intake to 50-75 g/day, reduction in fiber, alcohol, calcium and magnesium containing antacids; **Histamine-2 receptor blockers or Proton pump inhibitors; 'Small intestinal bacterial overgrowth, giardiasis, blind loop syndrome, malabsorption of other etiology.

timing of administration. Studies have demonstrated that efficacy is maximum if medications are taken during and after a meal, and such a schedule may need to be detailed with the patient. ${ }^{5,120}$ Although wide variation has been noted between products, ${ }^{106,107,111}$ at this point there is inadequate information to recommend changing formulation if the medication is not working, although this is not an unreasonable practice, given the fact that there are documented differences in delivery and release among the marketed products. ${ }^{117,118}$ Certainly, in areas in which generic medications are available, if the medication loses its clinical effect in an individual, it should be determined if the medication has been changed to a generic form, and changed to brand name medication if appropriate. If compliance is in question, a fecal chymotrypsin test can be performed to confirm compliance. If these possibilities are eliminated as primary causes of loss of clinical effect, and secondary causes of diarrhea are less likely by history and exam, the first option is to increase the amount of lipase given to see if response improves. If this is not successful, dietary habits may need modification, in particular, a reduction in lipid intake to 50 to $75 \mathrm{~g}$ per day. ${ }^{71}$ Other treatment modifications may include reduction in fiber intake, avoidance of alcohol, and minimizing calcium- and magnesium-containing antacids, as these can all increase steatorrhea. The next step is usually to administer acid-suppressing medications, either histamine-2 receptor blockers or proton pump inhibitors. Studies have shown improved lipid digestion and absorption with administration of acid-suppressing medications to nonenteric-coated formulations. ${ }^{144-146}$ Furthermore, it has been shown that acid suppression in addition to enteric-coated formulations will improve steatorrhea, and may enable the use of lower amounts of lipase. ${ }^{147}$ Finally, if all the above steps fail, diagnostic evaluation for other etiologies for continued steatorrhea is warranted, including small intestinal bacterial overgrowth, giardiasis, blind loop syndrome, and other absorptive problems. . $^{37,71,76}$

\section{Future developments for an optimal therapy The challenges of current obstacles to effective therapy}

Optimal lipid digestion and absorption is not always reached in EPI patients, which is assumed to be due largely to problems with delivery of active lipases at the appropriate intestinal site (duodenum) and time of delivery. Also, the amount and the type of enzymes administered fails to mimic normal human pancreatic secretion that is specific to age and to each individual. Treatment requires intake of multiple capsules and is expensive. Problems of allergy to porcine proteins and religious or other cultural concerns with the use of pork products also have to be taken into account. To address these issues, ongoing research is focusing on identifying new enzyme sources, more efficacious lipases, and strategies to enable improved delivery throughout the digestive process. Standardized, rapid, in vitro test systems to measure the efficacy of such lipases in near physiologic conditions need to be set up for screening and to help create more accurate PERT product labeling.

\section{Supplementation of duodenal bicarbonate}

Acidic degradation of exogenous pancreatic lipase and the discrepancy between an optimal $\mathrm{pH}$ for enzyme action and the actual intra-duodenal $\mathrm{pH}$ in EPI patients are major factors that prevent complete correction of steatorrhea. ${ }^{71}$ One answer is to increase the local duodenal $\mathrm{pH}$. The use of sodium bicarbonate ( $1.34 \mathrm{~g}$ per test meal) with enteric-coated tablets of pancreatic enzymes combined with desiccated ox bile (50 mg per test meal) considerably improved lipid digestion as measured by breath-test in patients with chronic pancreatitis, without concurrent acid-suppressive therapy. ${ }^{148}$ More recently, the effect of administering enteric-coated buffered pancrelipase microspheres (Pancrecarb MS-8, Digestive Care Inc, PA, USA) containing $2.5 \mathrm{mEq}^{149}$ or $1.5 \mathrm{mEq}^{150}$ of bicarbonate per capsule was tested on CFA in CF patients. In both studies, the number of patients, lipid consumption, stated lipases units/kg per day (about 4400 USP) were similar, and patients were their own controls. A significant increase in CFA (9\%) was observed only in the study providing the higher amount of sodium bicarbonate (about $6.9 \mathrm{~g}$ daily versus $3.1 \mathrm{~g}$ daily). ${ }^{149}$ The results of these 
studies are difficult to interpret, as individual responses to the buffered PERT varied widely, probably because $\mathrm{CF}$ patients can secrete either normal or high levels of gastric acid postprandially. ${ }^{98,151}$ As a result, there would be marked individual variability in duodenal $\mathrm{pH}$ as a response to the amount of bicarbonate provided.

\section{Alternative sources of lipases}

In order to avoid the short half-life of lipolytic enzymes of pancreatic origin for replacement therapy, a variety of lipases have been tested from sources as diverse as animal gastric lipase and microbial or plant lipases.

Supplementation with gastric lipase has been evaluated because of the natural acid-resistant properties and broad $\mathrm{pH}$ of action (3 to 6) of the enzyme..$^{51,152} \mathrm{~A}$ dog recombinant lipase, rGL, was produced to test this concept ${ }^{153}$ and was developed by the French company Meristem Therapeutics SA, Clermont-Ferrand (Merispase), that went out of business in September 2008. This approach is problematic for several reasons: gastric lipase specific activity is about 10 times lower than that of pancreatic lipase (measured on tributyrin) ${ }^{51}$ it is highly sensitive to trypsin proteolysis; ${ }^{154}$ and endogenous secretion of gastric lipase can be increased in patients with pancreatic insufficiency ${ }^{28}$ because of possible nutritional adaptation. ${ }^{98,155}$ However, gastric lipase supplements may still be a viable option. Indeed, during gastric lipolysis, endogenous human gastric lipase is rapidly trapped within fatty acid-rich particles generated at the surface of the lipid droplet and is no longer able to access its substrate. ${ }^{156}$ The addition of an extra dose of gastric lipase through supplementation will allow lipolysis to continue. ${ }^{156}$ Also, in vivo specific activity of gastric lipase can be close to that of pancreatic lipase especially on a solid food matrix. ${ }^{38}$ Two clinical trials conducted in CF patients showed that rGL is well tolerated and efficient when administered at the dose of $600 \mathrm{mg}$ alone, or when associated with pancreatic extract (PE) ( $\geq 300,000$ UPS total per day). This combination led to a significantly increased CFA compared with PE alone (84\% vs $71 \%$ ) in 7 of 11 patients. ${ }^{157}$ Another study showed that $250 \mathrm{mg}$ rGL combined with a low dose of pancreatic extract led to at least equal CFA compared with a high dose of PE. ${ }^{158}$ Furthermore, there was a greater benefit in CF patients with low CFA, which also improved quality of life. ${ }^{158}$

Microbial lipases of fungal or bacterial origin are of potential interest because of their acid and protease-stable properties and their activity at $\mathrm{pH} 3$ to 10 . Rhizopus arrhizus, ${ }^{159}$ Candida cylindacea, Aspergillus niger, ${ }^{160,161}$ and Yarrowia lipolytica ${ }^{162,163}$ are some examples of the most tested fungi. The Aspergillus and Yarrowia species have better survival in the duodenal environment as shown in vitro and in rats, while the others appeared very sensitive to trypsin and to the detergent action of bile salts. Lipases derived from bacteria are more promising as they are highly resistant to both acid and alkaline inactivation, stable in the presence of both proteolytic enzymes and bile salts, and active without the need for bile salts and colipase. ${ }^{164}$ A novel, experimental type of enzyme supplement containing bacterial lipase, fungal protease, and amylase (TheraCLEC-Total or ALTU135, Altus Pharmaceuticals, MA, USA) has demonstrated good tolerance and efficacy (20\% increase in CFA). ${ }^{164} \mathrm{~A}$ Phase II clinical trial showed that a moderate dose $(25,000$ USP of lipase per meal) resulted in a $35 \%$ to $40 \%$ increase in the CFA of cystic fibrosis patients with $0 \%$ to $40 \%$ CFA at baseline, and that a high dose (100,000 USP lipase per meal) was necessary for a $10 \%$ increase in the CFA of patients with $41 \%$ to $80 \%$ baseline CFA, after 1 month's treatment. ${ }^{165} \mathrm{~A}$ 1-year, multi-center, Phase III clinical trial was completed in 2009 (ClinicalTrials.gov NCT00500084) and results are pending. ${ }^{166}$ Thus, Liprotamase (formerly known as ALTU135 and Trizytek), for which a pediatric formulation is in progress, is the first porcine-free PERT developed since the end of 2008 (Alnara Pharmaceuticals, MA, USA, acquired by Eli Lilly, IN, USA). ${ }^{167}$ A better knowledge of the microbial lipases structure and modes of action will probably help to select and design much more active enzymes in the near future. ${ }^{168,169}$

Plant acid-stable lipase, as in oats, ${ }^{170}$ and plant latex lipase extracts from euphorbia characias, fruit of babaco, or carica papaya ${ }^{171,172}$ are potential sources of lipases. At this point, kinetics have been studied only in vitro and scientific data are needed on their digestive function in physiological conditions.

\section{Recombinant human lipases}

Recombinant human lipases would be expected to offer superior safety by decreasing the risk of allergic reactions. Progress in protein engineering ${ }^{173}$ and a detailed knowledge of human lipases ${ }^{174}$ will enable large-scale production and the ability to apply directed mutagenesis if necessary for improving lipase stability and activity in acidic conditions. Of note, the use of recombinant human lipases may be limited by the fact that changes in glycosylation (rates and type) and other post-translational modifications in proteins produced in the non-eukaryotic cell system used for large-scale production may interfere with enzymatic activity. ${ }^{175,176}$ 
A promising candidate for the treatment of lipid malabsorption is a recombinant human bile salt-stimulated lipase (rBSSL). This enzyme is naturally acid resistant and able to hydrolyze triglycerides and phospholipids. ${ }^{59}$ Two preparations dedicated to cystic fibrosis patients and preterm infants, Exinalda and Kiobrina, respectively, are currently under development (Biovitrum AB, Stockholm, Sweden). A Phase I clinical trial was conducted in $9 \mathrm{CF}$ patients with EPI, measuring lipid uptake through breath-test. ${ }^{177}$ The addition of rBSSL $(0.2$ or $1 \mathrm{~g})$ to standard pancrelipase (Creon) enabled a dose reduction of pancrelipase to $25 \%$ of normal dose. ${ }^{177}$ Plasma chylomicron level was significantly higher with the addition of rBSSL (34\% to $48 \%$ ), a clear secretion peak being reached at 3 hours after the meal, ${ }^{177}$ which is similar to the pattern found in normal subjects, ${ }^{30}$ while no real peak was observed with pancrelipase dosing alone. This can be explained by the ability of BSSL to generate lysophospholipids necessary for an efficient lipid absorption rate by the small intestine,${ }^{61}$ and to participate in chylomicron assembly and secretion through its ceramidase activity. ${ }^{14}$ Another study was conducted through 2009 with Exinalda in $18 \mathrm{CF}$ patients with EPI in Poland and the Netherlands, but the results have not yet been published (ClinicalTrials. gov NCT00743483). Two Phase II clinical trials have been conducted in Italy and France with Kiobrina administered at a dose physiologically found in human milk $(0.15 \mathrm{~g} / \mathrm{L})$ for 1 week to premature infants in formula (ClinicalTrials.gov NCT00658905) or in pasteurized breast milk (ClinicalTrials. gov NCT00659243), but results are not yet available.

Directional mutagenesis and use of electrostatic computations has also allowed generation of a human pancreatic lipase with modified $\mathrm{pH}$ of action $(\mathrm{pH} 4-5) .{ }^{178}$ Pancreatic lipase is irreversibly inactivated by gastric acid at a $\mathrm{pH}$ of 4.0 and below and its activity is very low at $\mathrm{pH}$ 5.0. ${ }^{10}$ Several variants of the recombinant human pancreatic lipase were generated by error-prone PCR and screened for stability and activity at a $\mathrm{pH}$ of 5 in vitro. ${ }^{179}$ Although these enzymes were more acid stable, their activity on physiologic substrates was not enhanced compared to native human pancreatic lipase.

\section{Delivery system strategies}

Bacterial engineering and gene transfer techniques could revolutionize the delivery of pancreatic enzymes by producing the enzymes within the host. Strains of bacteria such as Lactococcus lactis, genetically modified to highly express bacterial lipases, have been derived. ${ }^{180}$ Colonization of pigs with experimentally induced pancreatic insufficiency with lipase-producing L. lactis demonstrated increased CFA under a high-fat diet. ${ }^{181}$ The treatment occurs as the bacteria release their cellular content in response to contact with proteolytic secretions and bile acids. ${ }^{181}$ A gene therapy approach could be envisioned as an alternative therapeutic strategy to improve lipid digestion and absorption in EPI patients by mediating enzyme production by transduced cells within the treated patient. Indeed, the human pancreatic lipase gene has been successfully expressed in the biliary tract in rats using recombinant adenovirus. ${ }^{182}$

\section{Strategies through substrate physicochemical properties and lipase activators}

As an alternative, creating functional dietary lipids that are more effectively digested is another frontier of treatment for pancreatic insufficiency. Triglyceride digestion is more efficient when the substrate is emulsified, ie, dispersed, in aqueous medium as lipid droplets which consist in a core of triglycerides stabilized by a layer of phospholipids or other emulsifiers. The process of emulsification creates a lipid-water interface allowing optimal action of lipases. ${ }^{183}$ The physicochemical properties of such an interface can modulate the rate of lipolysis. ${ }^{183,184}$ Thus, structuring food emulsions is a new concept that should improve lipid digestion and absorption in EPI patients by selecting the best lipid physicochemical properties for optimal action of lipases. ${ }^{28,30,185,186}$

Lipid droplet size is one of the key physicochemical parameters of triglyceride digestion by gastric and pancreatic lipases, as it governs the lipid-water interface area. 29,30,155 Droplet size is inversely related to the lipid interface area, and, theoretically, small-sized droplets should be more efficiently digested in the digestive tract offering a larger interface area that will allow the binding of more lipase molecules at the interface. Indeed, it was shown in healthy humans that the triglycerides from small-sized droplets $(0.7 \mu \mathrm{m})$ are more efficiently digested in the stomach and in the duodenum than from larger droplets. ${ }^{30}$ Even though this has a potential for health, it has not been tested yet in EPI patients.

Another physicochemical key factor involved in lipid digestion is the ultrastructure, ie, droplet surface layer composition (phospholipid classes, phospholipid fatty acid profile, adsorbed proteins). ${ }^{184}$ Lipases bind to such a surface layer to access to triglycerides contained in the core of the droplet. The composition of the droplet surface layer plays a key role in vivo as it was shown that native human milk droplets of about $4 \mu \mathrm{m}$ (three phospholipid layers) were 
more efficiently lipolyzed in the stomach of premature babies than small-sized droplets $(0.5 \mu \mathrm{m})$ from a formula (single layer) ${ }^{56}$ It was shown in vitro that specific classes of phospholipids will prevent pancreatic lipase activity, ${ }^{187}$ or enhance dramatically gastric lipase, pancreatic lipase, and BSSL activity in conditions that mimic physiology. ${ }^{188,189}$ Also, the dietary protein interaction within the droplet surface can improve or diminish the triglycerides lipolysis rates. ${ }^{190}$

A third physicochemical property of lipids that is of particular importance in patients suffering from digestive and absorptive disorders is the triglyceride structure, ie, the nature of fatty acid esterified at positions sn-1, sn-2, and sn-3 of the glycerol backbone. ${ }^{191-194}$ Indeed, this structure influences digestion, as the lipolysis rate depends on the type of fatty acid present at the sn-1 and sn-3 positions, ${ }^{195}$ and the lipid droplet size can differ depending on the triglyceride structure. ${ }^{196}$ Triglyceride structure also affects i) the absorption step, as the fatty acid is better absorbed when it is present as a 2-monoglyceride; ${ }^{193,197,198}$ ii) the enterocyte re-synthesis step and the secretion of chylomicrons by the enterocyte, as the fatty acid of the sn-2 position is retained in chylomicron lipid particles; and iii) the lipid metabolism. ${ }^{198,199}$ So, the structure of triglycerides is particularly important to improve absorption of essential and very-long chain fatty acids. ${ }^{193,200}$ In contrast, absorption of long-chain saturated fatty acids can be dramatically decreased when present at the sn- 1 and sn-2 positions of the triglyceride molecule and in the presence of high concentration of calcium or magnesium, because they form insoluble soaps. ${ }^{197}$ Except for Betapol (Lipid Nutrition, Hogeweg, the Netherlands) used in several milk substitutes because it is a source of structured triglycerides with long-chain saturated fatty acids in sn-2 position, as in human milk, ${ }^{192,193}$ other kinds of structured triglycerides are not often used, probably because of their cost. ${ }^{193}$

Functional foods are a new area of research for clinical nutrition. For EPI patients, specific, more digestible or absorbable lipid sources could be designed. The addition of specific phospholipids able to enhance lipase activity in enzyme supplements or in formula would both increase lipase activity and, in parallel, enhance lipid nutrient absorption.

\section{Conclusion}

Exocrine pancreatic insufficiency results from a wide range of medical and surgical conditions. PERT is the standard treatment for the resultant malabsorption. Therapy is in general well tolerated and efficacy is satisfactory. Although progress has been made in standardizing therapy and improving enzyme formulations, there is still room to improve in terms of fully resolving the symptoms and malnutrition related to EPI, along with convenient and accurate means for monitoring therapy. In the clinical setting, a basic understanding of the physiology of enzyme delivery assists in choosing, monitoring, and adjusting therapy. Currently the most common monitoring strategy is clinical response, as stool fat and breath testing are cumbersome and less clinically available. Dose adjustments can be made according to the amount of steatorrhea and the patient's weight loss or gain. The common problem of incomplete response to therapy might also indicate that the mechanism of malabsorption in pancreatic insufficiency is more complex than simply a lack of pancreatic enzymes and electrolyte secretions, and further study in this area is warranted. In the future, with the advent of new technology, we look forward to delivering even better tolerated replacement therapy, which replicates more accurately the function of the native pancreas or delivers nutrition more effectively, and more convenient or available means of monitoring therapy.

\section{Disclosure}

The authors declare no conflict of interest.

\section{References}

1. Pezzilli R, Morselli Labate AM, Ceciliato R, et al. Quality of life in patients with chronic pancreatitis. Dig Liver Dis. 2005;37(3):181-189.

2. Whitcomb DC, Lehman GA, Vasileva G, et al. Pancrelipase delayedrelease capsules (CREON) for exocrine pancreatic insufficiency due to chronic pancreatitis or pancreatic surgery: A double-blind randomized trial. Am J Gastroenterol. 2010;105(10):2276-2286.

3. Ferrone M, Raimondo M, Scolapio JS. Pancreatic enzyme pharmacotherapy. Pharmacotherapy. 2007;27(6):910-920.

4. Yamada T, editor. Textbook of Gastroenterology. Fourth ed: Lippincott Williams \& Wilkins; 2003.

5. Bruno MJ, Haverkort EB, Tytgat GN, van Leeuwen DJ. Maldigestion associated with exocrine pancreatic insufficiency: implications of gastrointestinal physiology and properties of enzyme preparations for a cause-related and patient-tailored treatment. Am J Gastroenterol. 1995;90(9):1383-1393.

6. Adler G, Mullenhoff A, Koop I, et al. Stimulation of pancreatic secretion in man by a protease inhibitor (camostate). Eur J Clin Invest. 1988; 18(1):98-104

7. Braganza JM, Herman K, Hine P, Kay G, Sandle GI. Pancreatic enzymes in human duodenal juice-a comparison of responses in secretin pancreozymin and Lundh Borgstrom tests. Gut. 1978;19(5):358-366.

8. Escourrou J, Frexinos J, Ribet A. Biochemical studies of pancreatic juice collected by duodenal aspiration and endoscopic cannulation of the main pancreatic duct. Am J Dig Dis. 1978;23(2):173-177.

9. Berton A, Sebban-Kreuzer C, Rouvellac S, Lopez C, Crenon I. Individual and combined action of pancreatic lipase and pancreatic lipase-related proteins 1 and 2 on native versus homogenized milk fat globules. Mol Nutr Food Res. 2009;53(12):1592-1602.

10. Borgstrom B. Influence of bile salt, $\mathrm{pH}$, and time on the action of pancreatic lipase. Journal of Lipid Research. 1964;5:522-531.

11. Crenon I, Foglizzo E, Kerfelec B, et al. Pancreatic lipase-related protein type I: a specialized lipase or an inactive enzyme. Protein Eng. 1998; 11(2):135-142. 
12. De Caro J, Carrière F, Barboni P, Giller T, Verger R, De Caro A. Pancreatic lipase-related protein 1 (PLRP1) is present in the pancreatic juice of several species. Biochim Biophys Acta. 1998;1387(1-2): 331-341.

13. Eydoux C, Aloulou A, De Caro J, et al. Human pancreatic lipase-related protein 2: tissular localization along the digestive tract and quantification in pancreatic juice using a specific ELISA. Biochim Biophys Acta. 2006;1760(10):1497-1504.

14. Hui DY, Howles PN. Carboxyl ester lipase: structure-function relationship and physiological role in lipoprotein metabolism and atherosclerosis. J Lipid Res. 2002;43(12):2017-2030.

15. Jayne S, Kerfelec B, Foglizzo E, Chapus C, Crenon I. High expression in adult horse of PLRP2 displaying a low phospholipase activity. Biochim Biophys Acta. 2002;1594(4):255-265.

16. Lowe ME. The triglyceride lipases of the pancreas. J Lipid Res. 2002;43(12):2007-2016.

17. Reboul E, Berton A, Moussa M, Kreuzer C, Crenon I, Borel P. Pancreatic lipase and pancreatic lipase-related protein 2, but not pancreatic lipase-related protein 1 , hydrolyze retinyl palmitate in physiological conditions. Biochim Biophys Acta. 2006;1761(1):4-10.

18. Sias B, Ferrato F, Grandval P, et al. Human pancreatic lipase-related protein 2 is a galactolipase. Biochemistry. 2004;43(31):10138-10148.

19. Thirstrup K, Verger R, Carrière F. Evidence for a pancreatic lipase subfamily with new kinetic properties. Biochemistry. 1994;33(10): 2748-2756.

20. Verheij MH, Westerman J, Sternby B, de Haas GH. The complete primary structure of phospholipase A2 from human pancreas. Biochim Biophys Acta. 1983;747(1-2):93-99.

21. Lowe ME. The structure and function of pancreatic enzymes In: Johnson LR, Alpers DH, Christensen J, Jacobson ED, Walsh JH, editors. Physiology of the Gastrointestinal Tract. Vol 2. New York: Raven Press;1994:1531-1542.

22. Lebenthal E, Lee PC. Development of functional responses in human exocrine pancreas. Pediatrics. 1980;66(4):556-560.

23. Zoppi G, Andreotti G, Pajno-Ferrara F, Njai DM, Gaburro D. Exocrine pancreas function in premature and full term neonates. Pediatr Res. 1972;6(12):880-886.

24. Fredrikzon B, Olivecrona T. Decrease of lipase and esterase activities in intestinal contents of newborn infants during test meals. Pediatr Res. 1978;12(5):631-634.

25. Track NS, Creutzfeldt C, Bokermann M. Enzymatic, functional and ultrastructural development of the exocrine pancreas-II. The human pancreas. Comp Biochem Physiol A Comp Physiol. 1975;51(1A): 95-100.

26. Laugier R, Bernard JP, Berthezene P, Dupuy P. Changes in pancreatic exocrine secretion with age: pancreatic exocrine secretion does decrease in the elderly. Digestion. 1991;50(3-4):202-211.

27. Keller J, Layer P. Human pancreatic exocrine response to nutrients in health and disease. Gut. 2005;54 Suppl 6:vi1-vi28.

28. Armand M. Lipases and lipolysis in the human digestive tract: where do we stand? Curr Opin Clin Nutr Metab Care. 2007;10(2):156-164.

29. Armand M, Borel P, Pasquier B, et al. Physicochemical characteristics of emulsions during fat digestion in human stomach and duodenum. Am J Physiol. 1996;271(1 Pt 1):G172-G183.

30. Armand M, Pasquier B, Andre M, et al. Digestion and absorption of 2 fat emulsions with different droplet sizes in the human digestive tract. Am J Clin Nutr. 1999;70(6):1096-1106.

31. Schwizer W, Asal K, Kreiss C, et al. Role of lipase in the regulation of upper gastrointestinal function in humans. Am J Physiol. 1997; 273(3 Pt 1):G612-G620.

32. Boivin M, Lanspa SJ, Zinsmeister AR, Go VL, DiMagno EP. Are diets associated with different rates of human interdigestive and postprandial pancreatic enzyme secretion? Gastroenterology. 1990;99(6): 1763-1771.

33. Borovicka J, Schwizer W, Mettraux C, et al. Regulation of gastric and pancreatic lipase secretion by $\mathrm{CCK}$ and cholinergic mechanisms in humans. Am J Physiol. 1997;273(2 Pt 1):G374-G380.
34. Carrière F, Barrowman JA, Verger R, Laugier R. Secretion and contribution to lipolysis of gastric and pancreatic lipases during a test meal in humans. Gastroenterology. 1993;105(3):876-888.

35. Carrière F, Grandval P, Renou C, et al. Quantitative study of digestive enzyme secretion and gastrointestinal lipolysis in chronic pancreatitis. Clin Gastroenterol Hepatol. 2005;3(1):28-38.

36. Yago MD, Gonzalez MV, Martinez-Victoria E, et al. Pancreatic enzyme secretion in response to test meals differing in the quality of dietary fat (olive and sunflowerseed oils) in human subjects. Br J Nutr. 1997; 78(1):27-39

37. Layer P, Keller J. Pancreatic enzymes: secretion and luminal nutrient digestion in health and disease. J Clin Gastroenterol. 1999;28(1): $3-10$.

38. Carrière F, Renou C, Lopez V, et al. The specific activities of human digestive lipases measured from the in vivo and in vitro lipolysis of test meals. Gastroenterology. 2000;119(4):949-960.

39. Keller J, Runzi M, Goebell H, Layer P. Duodenal and ileal nutrient deliveries regulate human intestinal motor and pancreatic responses to a meal. Am J Physiol. 1997;272(3 Pt 1):G632-G637.

40. Moreau H, Saunière JF, Gargouri Y, Pieroni G, Verger R, Sarles H. Human gastric lipase: variations induced by gastrointestinal hormones and by pathology. Scand J Gastroenterol. 1988;23(9):1044-1048.

41. Palasciano G, Saunières JF, Laugier R, Sarles H. Pancreatic response to secretin+CCK-PZ in European and North African adults and children. Gut. 1979;20(12):1063-1065.

42. Boehm G, Borte M, Muller H, Moro G, Minoli I. Activities of trypsin and lipase in duodenal aspirates of preterm infants: influence of dietary protein and fat composition. Am J Clin Nutr. 1995;61(3):524-527.

43. Mott C, Sarles H, Tiscornia O, Gullo L. Inhibitory action of alcohol on human exocrine pancreatic secretion. Am J Dig Dis. 1972;17(10): 902-910.

44. Bozkurt T, Adler G, Koop I, Koop H, Turmer W, Arnold R. Plasma CCK levels in patients with pancreatic insufficiency. Dig Dis Sci. 1988; 33(3):276-281.

45. Nouri-Sorkhabi MH, Chapman BE, Kuchel PW, Gruca MA, Gaskin KJ. Parallel secretion of pancreatic phospholipase A(2), phospholipase A(1), lipase, and colipase in children with exocrine pancreatic dysfunction. Pediatr Res. 2000;48(6):735-740.

46. Armand M. Milk fat digestibility. Sciences des Aliments. 2008;28(1-2): 84-98.

47. Mattes RD. Fat taste and lipid metabolism in humans. Physiol Behav. 2005;86(5):691-697.

48. Sarles H, Dani R, Prezelin G, Souville C, Figarella C. Cephalic phase of pancreatic secretion in man. Gut. 1968;9(2):214-221.

49. Solomon T. Control of exocrine pancreas secretion. In: LR J, editor. Physiology of the Gastrointestinal Tract. Vol 2. New York: Raven Press; 1994:1499-1529.

50. Alpers D. Digestion and absorption of carbohydrates and proteins. In: LR J, editor. Physiology of the Gastrointestinal Tract. Vol 2. New York: Raven Press; 1994:1723-1749.

51. Hamosh M. Lingual and gastric lipases. Nutrition. 1990;6(6):421-428.

52. MacGregor I, Parent J, Meyer JH. Gastric emptying of liquid meals and pancreatic and biliary secretion after subtotal gastrectomy or truncal vagotomy and pyloroplasty in man. Gastroenterology. 1977;72(2): 195-205.

53. Mayer EA, Thompson JB, Jehn D, Reedy T, Elashoff J, Meyer JH. Gastric emptying and sieving of solid food and pancreatic and biliary secretion after solid meals in patients with truncal vagotomy and antrectomy. Gastroenterology. 1982;83(1 Pt 2):184-192.

54. Chey WY, Chang T. Neural hormonal regulation of exocrine pancreatic secretion. Pancreatology. 2001;1(4):320-335.

55. Armand M, Borel P, Dubois C, et al. Characterization of emulsions and lipolysis of dietary lipids in the human stomach. Am J Physiol. 1994;266(3 Pt 1):G372-G381.

56. Armand M, Hamosh M, Mehta NR, et al. Effect of human milk or formula on gastric function and fat digestion in the premature infant. Pediatr Res. 1996;40(3):429-437. 
57. Bordalo O, Goncalves D, Noronha M, Cristina ML, Salgadinho A, Dreiling DA. Newer concept for the pathogenesis of chronic alcoholic pancreatitis. Am J Gastroenterol. 1977;68(3):278-285.

58. Dahim M, Brockman H. How colipase-fatty acid interactions mediate adsorption of pancreatic lipase to interfaces. Biochemistry. 1998;37(23): 8369-8377.

59. Lindquist $\mathrm{S}$, Hernell O. Lipid digestion and absorption in early life: an update. Curr Opin Clin Nutr Metab Care. 2010;13(3):314-320.

60. Lowe ME, Kaplan MH, Jackson-Grusby L, D'Agostino D, Grusby MJ. Decreased neonatal dietary fat absorption and $\mathrm{T}$ cell cytotoxicity in pancreatic lipase-related protein 2-deficient mice. J Biol Chem. 1998; 273(47):31215-31221.

61. Tso P. Intestinal lipid absorption. In: LR J, editor. Physiology of the Gastrointestinal Tract. Vol 2. New York: Raven Press; 1994: 1867-1908.

62. Hernell O, Staggers JE, Carey MC. Physical-chemical behavior of dietary and biliary lipids during intestinal digestion and absorption. 2. Phase analysis and aggregation states of luminal lipids during duodenal fat digestion in healthy adult human beings. Biochemistry. 1990;29(8):2041-2056.

63. Mu H, Hoy CE. The digestion of dietary triacylglycerols. Prog Lipid Res. 2004;43(2):105-133.

64. Layer P, Yamamoto H, Kalthoff L, Clain JE, Bakken LJ, DiMagno EP. The different courses of early- and late-onset idiopathic and alcoholic chronic pancreatitis. Gastroenterology. 1994;107(5):1481-1487.

65. Roberts IM, Poturich C, Wald A. Utility of fecal fat concentrations as screening test in pancreatic insufficiency. Dig Dis Sci. 1986;31(10): 1021-1024.

66. Fine KD, Schiller LR. AGA technical review on the evaluation and management of chronic diarrhea. Gastroenterology. 1999;116(6): 1464-1486.

67. Ewald N, Raspe A, Kaufmann C, Bretzel RG, Kloer HU, Hardt PD. Determinants of exocrine pancreatic function as measured by fecal elastase-1 concentrations (FEC) in patients with diabetes mellitus. Eur J Med Res. 2009;14(3):118-122.

68. Naruse S, Ishiguro H, Ko SB, et al. Fecal pancreatic elastase: a reproducible marker for severe exocrine pancreatic insufficiency. J Gastroenterol. 2006;41(9):901-908.

69. Hahn JU, Kerner W, Maisonneuve P, Lowenfels AB, Lankisch PG. Low fecal elastase 1 levels do not indicate exocrine pancreatic insufficiency in type-1 diabetes mellitus. Pancreas. 2008;36(3):274-278.

70. Lankisch PG, Schmidt I, Konig H, et al. Faecal elastase 1: not helpful in diagnosing chronic pancreatitis associated with mild to moderate exocrine pancreatic insufficiency. Gut. 1998;42(4):551-554.

71. Layer P, Keller J. Lipase supplementation therapy: standards, alternatives, and perspectives. Pancreas. 2003;26(1):1-7.

72. Dominguez-Munoz JE. Pancreatic enzyme therapy for pancreatic exocrine insufficiency. Curr Gastroenterol Rep. 2007;9(2):116-122.

73. Montalto G, Soresi M, Carroccio A, et al. Lipoproteins and chronic pancreatitis. Pancreas. 1994;9(1):137-138.

74. Pezzilli R. Chronic pancreatitis: maldigestion, intestinal ecology and intestinal inflammation. World J Gastroenterol. 2009;15(14): 1673-1676.

75. Gielkens HA, Eddes EH, Vecht J, van Oostayen JA, Lamers CB, Masclee AA. Gallbladder motility and cholecystokinin secretion in chronic pancreatitis: relationship with exocrine pancreatic function. $J$ Hepatol. 1997;27(2):306-312.

76. Krishnamurty DM, Rabiee A, Jagannath SB, Andersen DK. Delayed release pancrelipase for treatment of pancreatic exocrine insufficiency associated with chronic pancreatitis. Ther Clin Risk Manag. 2009;5(3): $507-520$.

77. Long WB, Weiss JB. Rapid gastric emptying of fatty meals in pancreatic insufficiency. Gastroenterology. 1974;67(5):920-925.

78. Mizushima T, Ochi K, Ichimura M, Kiura K, Harada H, Koide N. Pancreatic enzyme supplement improves dysmotility in chronic pancreatitis patients. J Gastroenterol Hepatol. 2004;19(9): 1005-1009.

79. Nustede R, Kohler H, Folsch UR, Schafmayer A. Plasma concentrations of neurotensin and CCK in patients with chronic pancreatitis with and without enzyme substitution. Pancreas. 1991;6(3):260-265.
80. Vu MK, Vecht J, Eddes EH, Biemond I, Lamers CB, Masclee AA. Antroduodenal motility in chronic pancreatitis: are abnormalities related to exocrine insufficiency? Am J Physiol Gastrointest Liver Physiol. 2000;278(3):G458-G466.

81. Czako L, Hegyi P, Rakonczay Z Jr, Wittmann T, Otsuki M. Interactions between the endocrine and exocrine pancreas and their clinical relevance. Pancreatology. 2009;9(4):351-359.

82. Bragelmann R, Armbrecht U, Rosemeyer D, Schneider B, Zilly W, Stockbrugger RW. The effect of pancreatic enzyme supplementation in patients with steatorrhoea after total gastrectomy. Eur J Gastroenterol Hepatol. 1999;11(3):231-237.

83. Creutzfeldt W, Gleichmann D, Otto J, Stockmann F, Maisonneuve P, Lankisch PG. Follow-up of exocrine pancreatic function in type-1 diabetes mellitus. Digestion. 2005;72(2-3):71-75.

84. Lankisch PG, Manthey G, Otto J, et al. Exocrine pancreatic function in insulin-dependent diabetes mellitus. Digestion. 1982;25(3): 211-216.

85. Hardt PD, Hauenschild A, Nalop J, et al. High prevalence of exocrine pancreatic insufficiency in diabetes mellitus. A multicenter study screening fecal elastase 1 concentrations in 1,021 diabetic patients. Pancreatology. 2003;3(5):395-402.

86. Sarles H. Etiopathogenesis and definition of chronic pancreatitis. Dig Dis Sci. 1986;31(9 Suppl):91S-107S.

87. Sarles H, Bernard JP, Gullo L. Pathogenesis of chronic pancreatitis. Gut. 1990;31(6):629-632.

88. Comfort MW, Gambrill EE, Baggenstoss AH. Chronic relapsing pancreatitis. A study of twenty-nine cases without associated disease of the biliary or gastro-intestinal tract. Gastroenterology. 1968; 54(4):Suppl:760-765.

89. Kloppel G, Maillet B. Chronic pancreatitis: evolution of the disease. Hepatogastroenterology. 1991;38(5):408-412.

90. Braganza JM. Pancreatic disease: a casualty of hepatic "detoxification"? Lancet. 1983;2(8357):1000-1003.

91. Ekstrom G, Ingelman-Sundberg M. Rat liver microsomal NADPHsupported oxidase activity and lipid peroxidation dependent on ethanol-inducible cytochrome P-450 (P-450IIE1). Biochem Pharmacol. 1989;38(8):1313-1319.

92. Marshall WJ, McLean AE. A requirement for dietary lipids for induction of cytochrome P-450 by phenobarbitone in rat liver microsomal fraction. Biochem J. 1971;122(4):569-573.

93. Cavallini G. Is chronic pancreatitis a primary disease of the pancreatic ducts? A new pathogenetic hypothesis. Ital J Gastroenterol. 1993; 25(7):391-396.

94. DiMagno MJ, DiMagno EP. Chronic pancreatitis. Curr Opin Gastroenterol. 2005;21(5):544-554.

95. Stevens T, Conwell DL, Zuccaro G. Pathogenesis of chronic pancreatitis: an evidence-based review of past theories and recent developments. Am J Gastroenterol. 2004;99(11):2256-2270.

96. Wilschanski M, Durie PR. Patterns of GI disease in adulthood associated with mutations in the CFTR gene. Gut. 2007;56(8):1153-1163.

97. Armand M, Hamosh M, Philpott JR, et al. Gastric function in children with cystic fibrosis: effect of diet on gastric lipase levels and fat digestion. Pediatr Res. 2004;55(3):457-465.

98. Andersen JR, Bendtsen F, Ovesen L, Pedersen NT, Rune SJ, Tage-Jensen U. Pancreatic insufficiency. Duodenal and jejunal pH, bile acid activity, and micellar lipid solubilization. Int J Pancreatol. 1990;6(4):263-270.

99. Dutta SK, Russell RM, Iber FL. Influence of exocrine pancreatic insufficiency on the intraluminal $\mathrm{pH}$ of the proximal small intestine. Dig Dis Sci. 1979;24(7):529-534.

100. Dutta SK, Russell RM, Iber FL. Impaired acid neutralization in the duodenum in pancreatic insufficiency. Dig Dis Sci. 1979;24(10): 775-780.

101. Bruno MJ, Rauws EA, Hoek FJ, Tytgat GN. Comparative effects of adjuvant cimetidine and omeprazole during pancreatic enzyme replacement therapy. Dig Dis Sci. 1994;39(5):988-992.

102. Chauhan S, Forsmark CE. Pain management in chronic pancreatitis: A treatment algorithm. Best Pract Res Clin Gastroenterol. 2010;24(3): 323-335. 
103. Massicotte LP, Baille WE, Mateescu MA. Carboxylated high amylose starch as pharmaceutical excipients. Structural insights and formulation of pancreatic enzymes. Int J Pharm. 2008;356(1-2): 212-223.

104. Naikwade SR, Meshram RN, Bajaj AN. Preparation and in vivo efficacy study of pancreatin microparticles as an enzyme replacement therapy for pancreatitis. Drug Dev Ind Pharm. 2009;35(4): 417-432.

105. Robinson PJ, Smith AL, Sly PD. Duodenal $\mathrm{pH}$ in cystic fibrosis and its relationship to fat malabsorption. Dig Dis Sci. 1990;35(10): 1299-1304.

106. Aloulou A, Puccinelli D, Sarles J, Laugier R, Leblond Y, Carrière F. In vitro comparative study of three pancreatic enzyme preparations: dissolution profiles, active enzyme release and acid stability. Aliment Pharmacol Ther. 2008;27(3):283-292.

107. Kraisinger M, Hochhaus G, Stecenko A, Bowser E, Hendeles L. Clinical pharmacology of pancreatic enzymes in patients with cystic fibrosis and in vitro performance of microencapsulated formulations. J Clin Pharmacol. 1994;34(2):158-166.

108. Case CL, Henniges F, Barkin JS. Enzyme content and acid stability of enteric-coated pancreatic enzyme products in vitro. Pancreas. 2005;30(2):180-183.

109. Meyer JH, Elashoff J, Porter-Fink V, Dressman J, Amidon GL. Human postprandial gastric emptying of 1-3-millimeter spheres. Gastroenterology. 1988;94(6):1315-1325.

110. Meyer JH, Lake R. Mismatch of duodenal deliveries of dietary fat and pancreatin from enterically coated microspheres. Pancreas. 1997; 15(3):226-235

111. Hendeles L, Dorf A, Stecenko A, Weinberger M. Treatment failure after substitution of generic pancrelipase capsules. Correlation with in vitro lipase activity. JAMA. 1990;263(18):2459-2461.

112. Traynor K. FDA approves third pancrelipase product: Unapproved products illegal to market after April 28. Am J Health Syst Pharm. 2010;67(10):776.

113. Graff GR, Maguiness K, McNamara J, et al. Efficacy and tolerability of a new formulation of pancrelipase delayed-release capsules in children aged 7 to 11 years with exocrine pancreatic insufficiency and cystic fibrosis: a multicenter, randomized, double-blind, placebo-controlled, two-period crossover, superiority study. Clin Ther. 2010;32(1): 89-103.

114. Graff GR, McNamara J, Royall J, Caras S, Forssmann K. Safety and tolerability of a new formulation of pancrelipase delayed-release capsules (CREON) in children under seven years of age with exocrine pancreatic insufficiency due to cystic fibrosis: an open-label, multicentre, single-treatment-arm study. Clin Drug Investig. 2010; 30(6):351-364.

115. Trapnell BC, Maguiness K, Graff GR, Boyd D, Beckmann K, Caras S Efficacy and safety of Creon 24,000 in subjects with exocrine pancreatic insufficiency due to cystic fibrosis. J Cyst Fibros. 2009;8(6): 370-377.

116. Wooldridge JL, Heubi JE, Amaro-Galvez R, et al. EUR-1008 pancreatic enzyme replacement is safe and effective in patients with cystic fibrosis and pancreatic insufficiency. J Cyst Fibros. 2009;8(6): 405-417.

117. Lohr JM, Hummel FM, Pirilis KT, Steinkamp G, Korner A, Henniges F. Properties of different pancreatin preparations used in pancreatic exocrine insufficiency. Eur J Gastroenterol Hepatol. 2009;21(9): 1024-1031.

118. Walters MP, Littlewood JM. Pancreatin preparations used in the treatment of cystic fibrosis - lipase content and in vitro release. Aliment Pharmacol Ther. 1996;10(3):433-440.

119. Kolbel C, Layer P, Hotz J, Goebell H. Effect of an acid protected, micro-encapsulated pancreatin preparation on pancreatogenic steatorrhea. Med Klin (Munich). 1986;81(3):85-86.

120. Dominguez-Munoz JE, Iglesias-Garcia J, Iglesias-Rey M, Figueiras A, Vilarino-Insua M. Effect of the administration schedule on the therapeutic efficacy of oral pancreatic enzyme supplements in patients with exocrine pancreatic insufficiency: a randomized, three-way crossover study. Aliment Pharmacol Ther. 2005;21(8): 993-1000.

121. O'Keefe SJ, Cariem AK, Levy M. The exacerbation of pancreatic endocrine dysfunction by potent pancreatic exocrine supplements in patients with chronic pancreatitis. J Clin Gastroenterol. 2001;32(4): 319-323.
122. Safdi M, Bekal PK, Martin S, Saeed ZA, Burton F, Toskes PP. The effects of oral pancreatic enzymes (Creon 10 capsule) on steatorrhea: a multicenter, placebo-controlled, parallel group trial in subjects with chronic pancreatitis. Pancreas. 2006;33(2):156-162.

123. Stern RC, Eisenberg JD, Wagener JS, et al. A comparison of the efficacy and tolerance of pancrelipase and placebo in the treatment of steatorrhea in cystic fibrosis patients with clinical exocrine pancreatic insufficiency. Am J Gastroenterol. 2000;95(8):1932-1938.

124. Baker SS. Delayed release pancrelipase for the treatment of pancreatic exocrine insufficiency associated with cystic fibrosis. Ther Clin Risk Manag. 2008;4(5):1079-1084.

125. Baker SS, Borowitz D, Duffy L, Fitzpatrick L, Gyamfi J, Baker RD. Pancreatic enzyme therapy and clinical outcomes in patients with cystic fibrosis. J Pediatr. 2005;146(2):189-193.

126. Dominguez-Munoz JE, Iglesias-Garcia J. Oral pancreatic enzyme substitution therapy in chronic pancreatitis: is clinical response an appropriate marker for evaluation of therapeutic efficacy? JOP. 2010;11(2):158-162.

127. Lembcke B, Braden B, Caspary WF. Exocrine pancreatic insufficiency: accuracy and clinical value of the uniformLy labelled 13C-Hiolein breath test. Gut. 1996;39(5):668-674.

128. Ritz MA, Fraser RJ, Di Matteo AC, et al. Evaluation of the 13C-triolein breath test for fat malabsorption in adult patients with cystic fibrosis. J Gastroenterol Hepatol. 2004;19(4):448-453.

129. Ventrucci M, Cipolla A, Ubalducci GM, Roda A, Roda E. 13C labelled cholesteryl octanoate breath test for assessing pancreatic exocrine insufficiency. Gut. 1998;42(1):81-87.

130. Vantrappen GR, Rutgeerts PJ, Ghoos YF, Hiele MI. Mixed triglyceride breath test: a noninvasive test of pancreatic lipase activity in the duodenum. Gastroenterology. 1989;96(4):1126-1134.

131. Nakamura H, Morifuji M, Murakami Y, et al. Usefulness of a 13C-labeled mixed triglyceride breath test for assessing pancreatic exocrine function after pancreatic surgery. Surgery. 2009;145(2): $168-175$.

132. Dominguez-Munoz JE, Iglesias-Garcia J, Vilarino-Insua M, Iglesias-Rey M. 13C-mixed triglyceride breath test to assess oral enzyme substitution therapy in patients with chronic pancreatitis. Clin Gastroenterol Hepatol. 2007;5(4):484-488.

133. Colombo C, Fredella C, Russo MC, et al. Efficacy and tolerability of Creon for Children in infants and toddlers with pancreatic exocrine insufficiency caused by cystic fibrosis: an open-label, single-arm, multicenter study. Pancreas. 2009;38(6):693-699.

134. Shafiq N, Rana S, Bhasin D, et al. Pancreatic enzymes for chronic pancreatitis. Cochrane Database Syst Rev. 2009;4:CD006302.

135. Stapleton FB, Kennedy J, Nousia-Arvanitakis S, Linshaw MA. Hyperuricosuria due to high-dose pancreatic extract therapy in cystic fibrosis. N Engl J Med. 1976;295(5):246-248.

136. Hauser R, Duty S, Godfrey-Bailey L, Calafat AM. Medications as a source of human exposure to phthalates. Environ Health Perspect. 2004;112(6):751-753.

137. FitzSimmons SC, Burkhart GA, Borowitz D, et al. High-dose pancreatic-enzyme supplements and fibrosing colonopathy in children with cystic fibrosis. N Engl J Med. 1997;336(18):1283-1289.

138. Bansi DS, Price A, Russell C, Sarner M. Fibrosing colonopathy in an adult owing to over use of pancreatic enzyme supplements. Gut. 2000;46(2):283-285.

139. Van Velzen D, Ball LM, Dezfulian AR, Southgate A, Howard CV. Comparative and experimental pathology of fibrosing colonopathy. Postgrad Med J. 1996;72 Suppl 2:S39-S48; discussion S49-S51.

140. Smyth RL, Ashby D, O'Hea U, et al. Fibrosing colonopathy in cystic fibrosis: results of a case-control study. Lancet. 1995;346(8985): 1247-1251.

141. Prescott P, Bakowski MT. Pathogenesis of fibrosing colonopathy: the role of methacrylic acid copolymer. Pharmacoepidemiol Drug Saf. 1999;8(6):377-384.

142. Prescott P. Pancreatic enzymes and fibrosing colonopathy. Lancet. 1999;354(9174):250; author reply 251 
143. Gaia E, Sambatoro A, De Giuli P, Angeli A. Adult fibrosing colonopathy associated with mesalazine treatment. Am J Gastroenterol. 2001;96(8):2508-2509.

144. Regan PT, Malagelada JR, Dimagno EP, Go VL. Rationale for the use of cimetidine in pancreatic insufficiency. Mayo Clin Proc. 1978;53(2): 79-83.

145. Durie PR, Bell L, Linton W, Corey ML, Forstner GG. Effect of cimetidine and sodium bicarbonate on pancreatic replacement therapy in cystic fibrosis. Gut. 1980;21(9):778-786.

146. Carroccio A, Pardo F, Montalto G, et al. Use of famotidine in severe exocrine pancreatic insufficiency with persistent maldigestion on enzymatic replacement therapy. A long-term study in cystic fibrosis. Dig Dis Sci. 1992;37(9):1441-1446.

147. Vecht J, Symersky T, Lamers CB, Masclee AA. Efficacy of lower than standard doses of pancreatic enzyme supplementation therapy during acid inhibition in patients with pancreatic exocrine insufficiency. J Clin Gastroenterol. 2006;40(8):721-725.

148. Vukovic M, Jojic N. Effect of enteric coated sodium bicarbonate, enzymes and bile combination on the absorption of fat in chronic pancreatitis. Ann Gastroenterol. 2000;13(2):113-117.

149. Brady MS, Garson JL, Krug SK, et al. An enteric-coated high-buffered pancrelipase reduces steatorrhea in patients with cystic fibrosis: a prospective, randomized study. J Am Diet Assoc. 2006;106(8): 1181-1186.

150. Kalnins D, Ellis L, Corey M, et al. Enteric-coated pancreatic enzyme with bicarbonate is equal to standard enteric-coated enzyme in treating malabsorption in cystic fibrosis. J Pediatr Gastroenterol Nutr. 2006; 42(3):256-261.

151. Barraclough M, Taylor CJ. Twenty-four hour ambulatory gastric and duodenal $\mathrm{pH}$ profiles in cystic fibrosis: effect of duodenal hyperacidity on pancreatic enzyme function and fat absorption. J Pediatr Gastroenterol Nutr. 1996;23(1):45-50.

152. Aloulou A, Carrière F. Gastric lipase: an extremophilic interfacial enzyme with medical applications. Cell Mol Life Sci. 2008;65(6): 851-854.

153. Gruber V, Berna P, Arnaud T, et al. Large-scale production of a therapeutic protein in transgenic tobacco plants: effect of subcellular targeting on quality of a recombinant dog gastric lipase. Mol Breed. 2001;7:329-340.

154. Bernback S, Blackberg L. Human gastric lipase. The N-terminal tetrapeptide is essential for lipid binding and lipase activity. Eur $J$ Biochem. 1989;182(3):495-499.

155. Armand M, Hamosh M, DiPalma JS, et al. Dietary fat modulates gastric lipase activity in healthy humans. Am J Clin Nutr. 1995;62(1): 74-80.

156. Pafumi Y, Lairon D, de la Porte PL, et al. Mechanisms of inhibition of triacylglycerol hydrolysis by human gastric lipase. J Biol Chem. 2002;277(31):28070-28079.

157. Lenoir GR, Knoop C, Durieu I, et al. Efficacy and safety of a recombinant gastric lipase produced in corn for the treatment of fat malabsorption in cystic fibrosis. [abstract] Pediatr Pulmonol. 2006; Suppl 29:293.

158. Lenoir G, Dubray C, Chiron R, et al. Recombinant gastric lipase (RGL) for the treatment of fat malabsorption. [abstract] Pediatr Pulmonol. 2008;Suppl 31:306.

159. Moreau J, Bouisson M, Saint-Marc-Girardin MF, Pignal F, Bommelaer G, Ribet A. Comparison of fungal lipase and pancreatic lipase in exocrine pancreatic insufficiency in man. Study of their in vitro properties and intraduodenal bioavailability. Gastroenterol Clin Biol. 1988;12(11): 787-792.

160. Griffin SM, Alderson D, Farndon JR. Acid resistant lipase as replacement therapy in chronic pancreatic exocrine insufficiency: a study in dogs. Gut. 1989;30(7):1012-1015.

161. Zentler-Munro PL, Assoufi BA, Balasubramanian K, et al. Therapeutic potential and clinical efficacy of acid-resistant fungal lipase in the treatment of pancreatic steatorrhoea due to cystic fibrosis. Pancreas. 1992;7(3):311-319.
162. Aloulou A, Puccinelli D, De Caro A, Leblond Y, Carrière F. A comparative study on two fungal lipases from Thermomyces lanuginosus and Yarrowia lipolytica shows the combined effects of detergents and $\mathrm{pH}$ on lipase absorption and activity. Biochim Biophys Acta. 2007;1771(12):1446-1456.

163. Turki S, Ayed A, Chalghoumi N, Weekers F, Thonart P, Kallel H. An enhanced process for the production of a highly purified extracellular lipase in the non-conventional yeast Yarrowia lipolytica. Appl Biochem Biotechnol. 2010;160(5):1371-1385.

164. Borowitz D, Goss CH, Limauro S, et al. Study of a novel pancreatic enzyme replacement therapy in pancreatic insufficient subjects with cystic fibrosis. J Pediatr. 2006;149(5):658-662.

165. Borowitz D, Goss CH, Stevens C, et al. Safety and preliminary clinical activity of a novel pancreatic enzyme preparation in pancreatic insufficient cystic fibrosis patients. Pancreas. 2006;32(3): 258-263.

166. Borowitz D, Falzone RP, Fratazzi C. A phase 3 study of the efficacy and safety of ALTU-135 (Trizytek) for treatment of pancreatic insufficiency in CF. [abstract] Pediatr Pulmonol. 2008; Supp1 31:423.

167. Aldridge S. Lilly snaps up Alnara. Nat Biotechnol. 2010;28:882.

168. Hasan F, Shah AA, Hameed A. Methods for detection and characterization of lipases: A comprehensive review. Biotechnol Adv. 2009;27(6):782-798.

169. Mala JG, Takeuchi S. Understanding structural features of microbial lipases-an overview. Anal Chem Insights. 2008;3:9-19.

170. Tursi JM, Phair PG, Barnes GL. Plant sources of acid stable lipases: potential therapy for cystic fibrosis. J Paediatr Child Health. 1994; 30(6):539-543.

171. Cambon E, Rodriguez JA, Pina M, et al. Characterization of typo-, regio-, and stereo-selectivities of babaco latex lipase in aqueous and organic media. Biotechnol Lett. 2008;30(4):769-774.

172. Moulin A, Teissere M, Bernard C, Pieroni G. Lipases of the euphorbiaceae family: purification of a lipase from Euphorbia characias latex and structure-function relationships with the B chain of ricin. Proc Natl Acad Sci U S A. 1994;91(24):11328-11332.

173. Quian Z, Fields CJ, Yu Y, Lutz S. Recent progress in engineering alpha/beta hydrolase-fold family members. Biotechnol J. 2007;2(2): 192-200.

174. Aloulou A, Rodriguez JA, Fernandez S, et al. Exploring the specific features of interfacial enzymology based on lipase studies. Biochim Biophys Acta. 2006;1761(9):995-1013.

175. Merten OW, Mattanovich D, Lang C, et al. editors. Recombinant Protein Production with Prokaryotic and Eukaryotic Cells. A Comparative View on Host Physiology. The Netherlands: Kluwer Academic Publishers; 2001.

176. Vitale A, Pedrazzini E. Recombinant pharmaceuticals from plants: the plant endomembrane system as bioreactor. Mol Interv. 2005; 5(4):216-225.

177. Strandvik B, Hansson L, Hernell O, et al. Recombinant human bile salt-stimulates lipase improves lipid uptake and reduces the pancreatic enzyme supplementation in patients with cystic fibrosis. [abstract] Pediatr Pulmonol. 2004;Suppl 27:333.

178. Neves-Petersen MT, Petersen EI, Fojan P, Noronha M, Madsen RG, Petersen SB. Engineering the $\mathrm{pH}$-optimum of a triglyceride lipase: from predictions based on electrostatic computations to experimental results. J Biotechnol. 2001;87(3):225-254.

179. Colin DY, Deprez-Beauclair P, Silva N, Infantes L, Kerfelec B. Modification of pancreatic lipase properties by directed molecular evolution. Protein Eng Des Sel. 2010;23(5):365-373.

180. Drouault S, Corthier G, Ehrlich SD, Renault P. Expression of the Staphylococcus hyicus lipase in Lactococcus lactis. Appl Environ Microbiol. 2000;66(2):588-598.

181. Drouault S, Juste C, Marteau P, Renault P, Corthier G. Oral treatment with Lactococcus lactis expressing Staphylococcus hyicus lipase enhances lipid digestion in pigs with induced pancreatic insufficiency. Appl Environ Microbiol. 2002;68(6):3166-3168. 
182. Kuhel DG, Zheng S, Tso P, Hui DY. Adenovirus-mediated human pancreatic lipase gene transfer to rat bile: gene therapy of fat malabsorption. Am J Physiol Gastrointest Liver Physiol. 2000;279(5): G1031-G1036.

183. Brockman H. General Features of Lipolysis: Reaction Scheme, Interfacial Structure and Experimental Approaches: Elsevier; 1984.

184. Favé G, Coste TC, Armand M. Physicochemical properties of lipids: new strategies to manage fatty acid bioavailability. Cell Mol Biol (Noisy-le-grand). 2004;50(7):815-831.

185. Golding M, Wooster TJ. The influence of emulsion structure and stability on lipid digestion. Curr Opin Colloid Interface Sci. 2010;15: 90-101.

186. Singh H, YeA, Horne D. Structuring food emulsions in the gastrointestinal tract to modify lipid digestion. Prog Lipid Res. 2009; 48(2):92-100.

187. Tsuzuki W, Ue A, Nagao A, Endo M, Abe M. Inhibitory effect of lysophosatidylcholine on pancreatic lipase-mediated hydrolysis in lipid emulsion. Biochim Biophys Acta. 2004;1684(1-3):1-7.

188. Armand M, Pieroni G, Inventors; Innovation Santé des Lipides (I.S.L.)/I.N.S.E.R.M., assignee. Foodstuff composition to improve digestibility of Foodstuff lipids. French patent WO 2009/037398, International Application No.: PCT/FR2008/001062

189. Favé G, Lévêque C, Peyrot J, Pieroni G, Coste TC, Armand M. Modulation of gastric lipolysis by the phospholipid specie: link to specific lipase-phospholipid interaction at the lipid/water interface? [abstract] FASEB Journal. 2007;21:A1010-a.

190. Mun S, Decker EA, McClements DJ. Influence of emulsifier type on in vitro digestibility of lipid droplets by pancreatic lipase. Food Res Intern. 2007;40(6):770-781.

191. Hubbard VS, McKenna MC. Absorption of safflower oil and structured lipid preparations in patients with cystic fibrosis. Lipids. 1987;22(6): 424-428.
192. Lucas A, Quinlan P, Abrams S, Ryan S, Meah S, Lucas PJ. Randomised controlled trial of a synthetic triglyceride milk formula for preterm infants. Arch Dis Child Fetal Neonatal Ed. 1997;77(3): F178-F184.

193. Mu H, Porsgaard T. The metabolism of structured triacylglycerols. Prog Lipid Res. 2005;44(6):430-448.

194. Tso P, Lee T, Demichele SJ. Lymphatic absorption of structured triglycerides vs physical mix in a rat model of fat malabsorption. Am J Physiol. 1999;277(2 Pt 1):G333-G340.

195. Jandacek RJ, Whiteside JA, Holcombe BN, Volpenhein RA, Taulbee JD. The rapid hydrolysis and efficient absorption of triglycerides with octanoic acid in the 1 and 3 positions and long-chain fatty acid in the 2 position. Am J Clin Nutr. 1987;45(5):940-945.

196. Kimura M, Shizuki M, Miyoshi K, et al. Relationship between the molecular structures and emulsification properties of edible oils. Biosci Biotechnol Biochem. 1994;58:1258-1261.

197. Bracco U. Effect of triglyceride structure on fat absorption. Am J Clin Nutr. 1994;60(6 Suppl):1002S-1009S.

198. Innis SM, Dyer RA, Lien EL. Formula containing randomized fats with palmitic acid (16:0) in the 2-position increases 16:0 in the 2-position of plasma and chylomicron triglycerides in formula-fed piglets to levels approaching those of piglets fed sow's milk. J Nutr 1997;127(7):1362-1370.

199. Kritchevsky D. Fatty acids, triglyceride structure, and lipid metabolism J Nutr Biochem. 1995;127(7):1362-1370.

200. Christensen MS, Hoy CE, Becker CC, Redgrave TG. Intestinal absorption and lymphatic transport of eicosapentaenoic (EPA), docosahexaenoic (DHA), and decanoic acids: dependence on intramolecular triacylglycerol structure. Am J Clin Nutr. 1995;61(1) $56-61$.
Clinical and Experimental Gastroenterology

\section{Publish your work in this journal}

Clinical and Experimental Gastroenterology is an international, peerreviewed, open access journal, publishing all aspects of gastroenterology in the clinic and laboratory, including: Pathology, pathophysiology of gastrointestinal disease; Investigation and treatment of gastointestinal disease; Pharmacology of drugs used in the alimentary tract;

\section{Dovepress}

Immunology/genetics/genomics related to gastrointestinal disease. This journal is indexed on CAS. The manuscript management system is completely online and includes a very quick and fair peer-review system. Visit http://www.dovepress.com/testimonials.php to read real quotes from published authors. 